\title{
原始生命誕生場で起こる岩石一水相互作用と 金属タンパク合成のための二次鉱物の役割
}

\author{
吉 屋一 美*+ 佐 藤 友 彦* \\ 大森 聡 一** 丸山茂 徳 ${ }^{* * * *}$ \\ Birthplace of Proto-life: Role of Secondary Minerals
in Forming Metallo-proteins through Water-Rock Interactions \\ Kazumi YOSHIYA*+, Tomohiko SATO*, \\ Soichi OMORI ${ }^{* *}$ and Shigenori MARUYAMA*,***
}

[Received 18 April, 2018; Accepted 25 May, 2018]

\begin{abstract}
The Hadean surface was mainly covered by three kinds of rock: komatiite, KREEP basalt, and anorthosite, which were remarkably different from those on the modern Earth. Water-rock interactions between these rocks and water provided a highly reducing environment and formed secondary minerals on the rock surface that are important for producing metallo-enzymes for the emergence of primordial life. Previous studies suggest a correlation with active sites of metallo-enzymes and sulfide minerals based on an affinity with their structure, but they do not discuss the origins of metallic elements contained in these minerals, which are critical to understand where primordial life was born. Secondary minerals formed through water-rock interactions of komatiite in a nuclear geyser system are investigated, followed by a discussion of the relationship between active sites of metallo-enzymes and secondary minerals. Instead of komatiite, we used serpentinite collected from Hakuba Happo area, Nagano Prefecture in central-north Japan, which is thought to be one of the Hadean modern analogues for the birthplace of life. Several minor minerals were found, including magnetite, chromite, pyrite, and pentlandite, in addition to the major serpentine minerals. Pentlandite is not been mentioned in previous studies as a candidate for supplying important metallic elements to form metallo-enzymes in previous studies. It also acts as a catalyst for hydrogen generation, because it closely resembles the structural features of an active site of hydrogenases. Nickel-iron sulfide, pentlandite, is considered to be one of the important minerals for the origin of life. In addition, what kinds of minor mineral would be obtained from water-rock interactions of these rocks is estimated using a thermo-dynamic calculation. KREEP basalt contains large amounts of iron, and it could be useful for producing metallo-enzymes, especially for ferredoxins, an electron transfer enzymes associated with the emergence of primordial life.
\end{abstract}

\footnotetext{
* 東京工業大学地球生命研究所

** 放送大学

***ノボシビルスク国立総合大学

+ 現所属 : 東京大学大学院理学系研究科

* Earth-Life Science Institute, Tokyo Institute of Technology, Tokyo, 152-8550, Japan

** The Open University of Japan, Chiba, 261-8586, Japan

*** Novosibirsk State University, Pirogova 1, 630090, Russia

+ Present address: Graduate School of Science, The University of Tokyo, Tokyo, 113-0033, Japan
} 
Key words : birth place of life, serpentinite, KREEP basalt, metallo-enzymes, metal sulfide キーワード：生命の誕生場，蛇紋岩，KREEP 立武岩，金属酵素，金属硫化鉱物

\section{I. はじめに}

生命の起源に関する研究は, 20 世紀の半ばに ユーリー・ミラーが行った実験によって，それま での神秘的で観念論の域をでなかった生命起源論 から実証科学としての新時代に突入した（Miller, 1953)。彼らの実験は，原始大気に模した大気ガ スと水を詰めたフラスコに, 強力な火花放電（電 磁波) エネルギーを加え, アミノ酸や簡単なタン パク質が無機的に合成できることを証明した。

一方，生物の観察，記載，分類においては，リ ンネ（1707-1778）が提案した生物の世界標準の 記載方法に従って, 今や大型多細胞生物は, 約 1,000 万種がすでに記載済みとなっている。さら に, ダーウィンの時代以降, 全世界で続々と記載 が進み, 地球全体ではさらに 1 桁多い生物種が 生息しているだろうと推測されている（Mora et al., 2011)。

分子生物学では, ワトソン・クリック (Watson and Crick, 1953）以降，遺伝子の解明が進み, 21 世紀に入ると, 真核単細胞生物の体積の 100 万分の 1 しかない原核生物（約 1 ミクロン）のゲ ノムが解析されるようになり，原核生物のゲノム の記載ブームを迎えている（たとえば, Hug et al., 2016)。

爆発的に増加するこのような記載学的な研究と ほぼ同時に，生命の起源に迫る第一歩としての生 命の誕生場を巡る論争がブームを迎えている。こ れまでに提案された生命の誕生場に関する仮説 は，(1）ダーウィンの栄養塩に満ちた暖かい小さ な池 (Darwin, 1859),（2）乾湿サイクルを繰り 返す潮間帯 (Oparin, 1957; Damer and Deamer, 2015)，（3）中央海嶺熱水系 (Corliss et al., 1981; Baross and Hoffman, 1985)，(4) 陸上島弧火山 の噴気孔（Mulkidjanian et al., 2012），(5）自 然原子炉間欠泉（Ebisuzaki and Maruyama,
2017），（6）火星起源説（Kirschvink and Weiss, 2003)，（7）宇宙に起源をもつとするパンスペル ミア説（Arrhenius, 1908）まで多様である。具 体的な実証実験に向けて，カオス的な状況を打開 するために, 生命誕生場に必要な条件を洗い出し まとめたのが Maruyama et al.（2018）である。 これまで生物学者を中心に無機的な出発物質から 生命誕生に向けて期待される代謝，膜，自己複製 機能に関わる実験や観察が行われてきたが，彼ら はそうした蓄積された情報を整理し，かつ，地質 学的な環境条件を加えて, 生命誕生場における束 縛条件を 9 つ抽出し，これまでに提案されている 生命誕生場の諸説を評価した（Maruyama et al., 2018）（表 1 ）。それによれば，9個の条件を満た すのは自然原子炉間欠泉以外に見当たらない（図 1 )。詳細についてはこの特集号の丸山による解 説を参照されたい（丸山ほか, 2019)。本稿では, 自然原子炉間欠泉内に存在した主要な 3 種類の 岩石（コマチアイト，KREEP 玄武岩，アノーソ サイト）と水の反応によって形成された二次鉱物 と，その鉱物からもたらされた始原生命のもつ代 謝との関係について議論する。

\section{II. 地球生命誕生場に必要な岩石種}

生命誕生にとって，水の存在は必要だが，水が あれば生命が生まれるということではない。大気 がなければアミノ酸を構成する窒素が供給され ず，大陸がなければ生命体の構成に必須であるリ ンやカリウムなど約 29 の栄養塩が供給されない。 つまり，大気・海洋・大陸の共存環境がなければ 生命誕生に至らない。こうした共存環境が生命誕 生場における必要最低限の条件だという考えは,

Dohm and Maruyama（2015）によって改めて 明示された Habitable Trinity とよばれる重要な 概念である。とくに，栄養塩は，生体に占める割 合としてはわずか $5 \%$ に満たないが，それがな 
表 1 生命誕生場における 9つの拘束条件（Maruyama et al., 2018）。これらの必要十分条件を満たすのは自然原子炉 間欠泉のみである。

Table 1 Nine requirements for the birth place of life (Maruyama et al., 2018). These essential requirements are only fulfilled by a nuclear geyser system.

\begin{tabular}{|c|c|c|c|c|c|}
\hline & Environmental factors & $\begin{array}{c}\text { Nuclear geyser } \\
\text { system }\end{array}$ & $\begin{array}{l}\text { Hydrothernal } \\
\text { system }\end{array}$ & $\operatorname{Mars}^{3}$ & Universe $^{4}$ \\
\hline 1 & Energy source (ionizing radiation + thermal energy) & Yes & No & Yes & Yes \\
\hline 2 & Supply of nutrients (P, K, KREEP etc.) & Yes & $?^{1}$ & Yes & No \\
\hline 3 & Supply of life constituent elements $(\mathrm{C}, \mathrm{H}, \mathrm{O}, \mathrm{N})$ & Yes & $?^{1}$ & Yes & Yes \\
\hline 4 & Concentration of reducing gas & Yes & No & $?^{2}$ & No \\
\hline 5 & Dry/Wet cycle & Yes & No & Yes & No \\
\hline 6 & Na-poor water & Yes & No & Yes & No \\
\hline 7 & Non-toxic water environment & Yes & No & $?^{2}$ & No \\
\hline 8 & $\begin{array}{l}\text { Diversified environments (Ocean } \mathrm{pH} \text {, salinity, heavy metals, } \\
\text { Atmosphere: Temperature \& Pressure, Continent varied } \\
\text { geology) }\end{array}$ & Yes & No & $?^{2}$ & No \\
\hline 9 & Cyclic nature & Yes & No & No & No \\
\hline
\end{tabular}

1. For some elements, Yes. But for others, No.

2. No evidence, but presumably Yes.

3. Mars kept ocean for the first 400 million years after the formation.

4. Universe does not have liquid water in the matrix.

ければ生命の誕生も生命維持も不可能である点 で，その存在が担う役割は大きい。では，これら の栄養塩の供給源である岩石にはどのようなタイ プがあり,どんな元素があるのだろうか？

\section{1）冥王代表層に存在した岩石種}

現在の地球では，大陸地殼（おもに花崗岩）は 表層面積の $1 / 3$ を占めており, 生体に必須な 29 種類の栄養塩元素の供給源となっている（Maruyama et al., 2013)。地球表層の大陸地殼以外の 部分はおもに玄武岩からなる海洋地款であり, 海 洋によって覆われている。生体にとって必要な元 素をバランスよく保有しているのは花崗岩であり, 玄武岩はリンの含有量が非常に低く, 栄養塩供給 源としては不十分である。では，冥王代の時代の 地球表層環境はどのようなものだったのだろうか?

冥王代の地球表層にどのような岩石が存在して いたかは長い間の謎だった。なぜなら，冥王代と よばれる 40-46 億年前の地層や岩石は約 42.8 億 年前のカナダ北東部・ヌブアギトゥク緑色岩帯の 偽角閃岩（O’Neil et al., 2008） と，オーストラリ ア西部・ジャックヒルズ磁岩（約 44 億年前）や
カナダ北西部・アカスタ片麻岩体に含まれる砕屑 性ジルコン（約 40 億年前）以外は現存していな いからである (Wilde et al., 2001; Iizuka et al., 2007; Valley et al., 2014 など)。冥王代の砕屑性 ジルコンに含まれる微量元素濃度や同位体組成か ら，その親マグマの組成が推定されている。冥王 代挽屑性ジルコンの多くは，液相濃集元素である ウラン濃度が高いことから親マグマは花崗岩質 （Grimes et al., 2007）あるいは液相濃集元素に 富む KREEP 玄武岩（Kemp et al., 2010）であっ たと考えられている。一方, 冥王代はマントルの ポテンシャル温度が高かったため, その表層を構 成する岩石はコマチアイトのような超苦鉄質岩が 主要だったとされている (Sleep, 2010 ほか)。 このように冥王代の地殼を構成する岩石につい ての情報は限られているが，近年，Maruyama and Ebisuzaki（2017）は，最新の地球形成論 (Imaeda and Ebisuzaki, 2017) と地球形成直後 のマグマオーシャンが固化する過程の結晶分化作 用のメカニズム (Arai and Maruyama, 2017), さらに月の地質記録（Wood et al., 1970; Taylor 


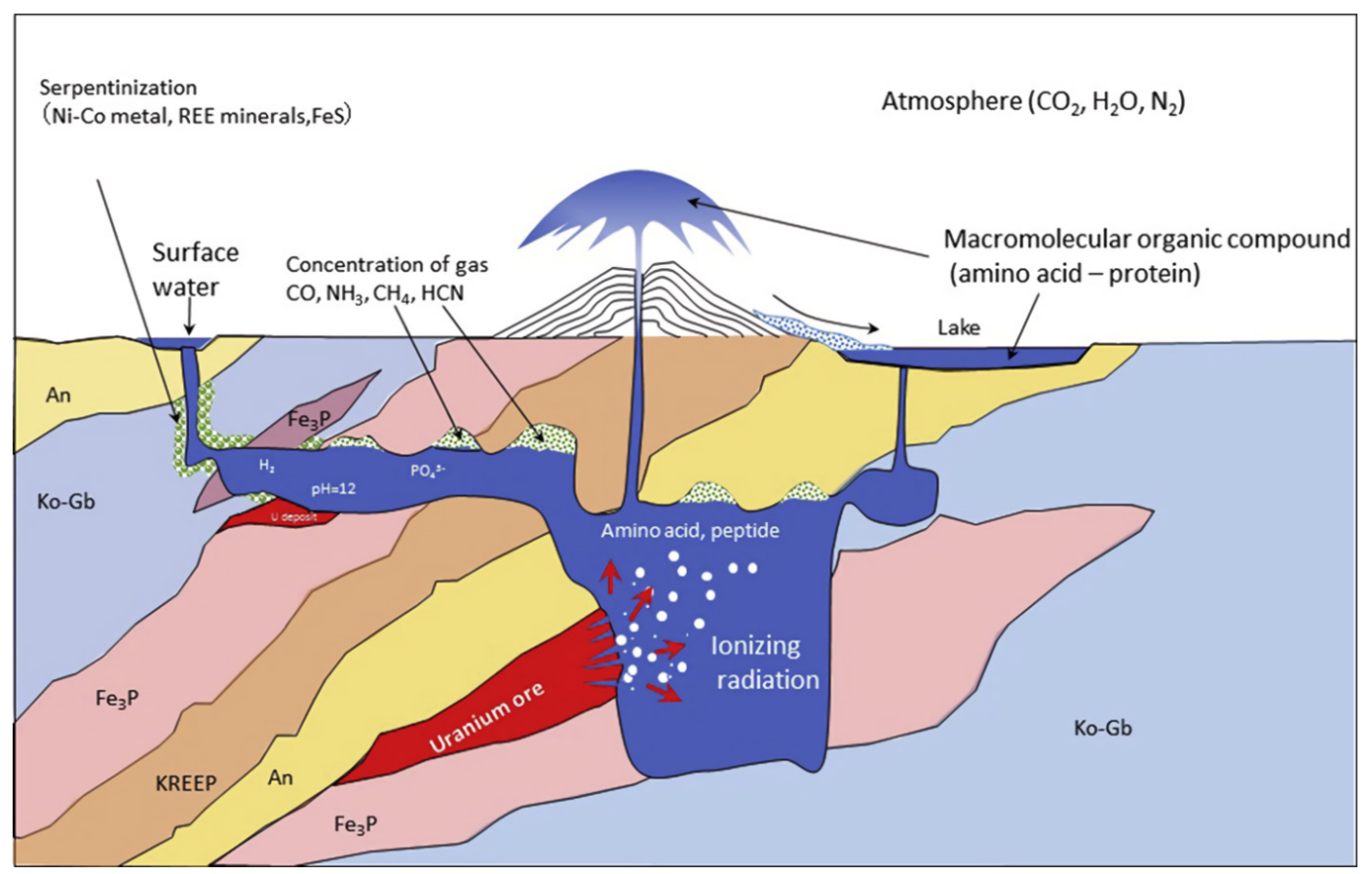

図 1 自然原子炉間欠泉の概念図（Ebisuzaki and Maruyama, 2017). 間欠泉のなかには冥王代表層に存在した主要な 岩石であるコマチアイト，KREEP玄武岩，アノーソサイトがある。この空隙に大気中の二酸化炭素や窒素，天 水により水が供給され, 非平衡状態で岩石と化学反応が起こる.

Fig. 1 Schematic figure of nuclear geyser system (Ebisuzaki and Maruyama, 2017). Several types of Hadean Earth rock were exposed at the geyser's interior including komatiite, KREEP basalt, and anorthosite. The water flowing into the geyser causes a water-rock interaction with wall rocks to produce reductive gases, which are essential for producing biomolecules.

and Jakes, 1974; Snyder et al., 1992; Krotev, 2005; Boyet and Carlson, 2007）をもとに，冥 王代地球の表層には原初大陸とよばれる巨大な大 陸があったことを導き出した。それによると，マ グマオーシャン固化後の地球表層には，アノーソ サイト，KREEP 玄武岩，コマチアイトとよばれ る3つの岩石種が卓越していた。これらの岩石 が低温で水と反応し，さまざまな二次変質鉱物が 生成され, 生命誕生の過程で重要な役割を果たし たと考えられる。

\section{2）生命誕生場で岩石が果たす役割}

リン，カリウム，鉄，カルシウム，マグネシウ ムといった代表的な栄養塩は，大気や海洋にはも ともと含まれていない。これらの元素は岩石に含 まれており，元素が水溶液中にイオンとして溶け
だすことによって，さまざまな物質と化学反応 し，新たな化合物をつくりだす。冥王代の地球表 層に存在した主要な岩石であるコマチアイト，

KREEP 玄武岩，アノーソサイトは，そうした栄 養塩を供給する岩石であり，生命の構成要素を合 成するための重要な物質を提供している。

なかでも遷移金属元素の供給は非常に重要であ り，生命とは何かという本質的な問いに直結して いる。生命とは絶え間ない電子の流れであり，そ うした電子の移動のためには遷移金属元素が必要 である。遷移金属元素がもつ酸化還元電位の差が 電子の流れを左右しているのである。具体的には, 生物の体内は超還元状態だが, 膜の外は酸化的環 境である。こうした酸化還元電位の差が生命現象 のはじまるきっかけであり，これら 2 つの相反 
する状態を繋ぐ物質循環は，遷移金属元素によっ て保たれているのである。実際，電子の移動を行 う多種多様なタンパク質のほとんどは，反応中心 （活性中心）に遷移金属元素が位置し，しばしば 硫黄と結合する。硫黄は酸化還元電位が最低の位 置（図 2 ）にあり，価数は -2 から +6 まで広い 幅をもつ。一方，硫黄の対となる鉄は地殼にもっ ともありふれた金属元素であり，冥王代の超還元 場では $\mathrm{Fe}^{2+}$ の状態で存在した。

ただし，それらの岩石がただ露出しているだけ では化学反応は進まない。岩石一水相互作用を通 して, 金属元素が水溶液中にイオンの形で溶出す ることが最初に必要である。

\section{3）岩石-水相互作用の重要性}

マグマオーシャンに覆われた原始地球が冷却し ていくと，カンラン石は 1 気圧 $1,000^{\circ} \mathrm{C}$ 以上で 晶出し, その成分が残液から除去される。その 後, 約 $1,000^{\circ} \mathrm{C}$ で輝石，マグマのなかに水があ れば $900^{\circ} \mathrm{C}$ で角閃石が晶出する。 $\mathrm{Mg}, \mathrm{Fe}$ を多 く含む苦鉄質鉱物が晶出することでマグマの成分 は徐々にシリカや斜長石に富む珪長質な成分に変 化しながら，液体のマグマから岩石を生成してい く。高温で晶出するカンラン石や輝石は，いった ん鉱物として晶出すると, 低温では容易に反応し ない。しかし，まったく反応が進まないのではな く, 非常にゆっくりと鉱物の表面部分でのみ水と の間に反応が起こる。通常 $350^{\circ} \mathrm{C}$ 以下（静水圧 による）で岩石表層の鉱物が変質し，その過程を 通じて鉱物中の金属元素がイオンの形で水中に溶 出するからである。こうして岩石から供給される イオン化した元素が栄養塩であり，そのほかの物 質と反応が可能になる。そのため, 岩石一水相互 作用は生命誕生にとってきわめて重要である。も ともと原初大陸の構成岩石は， $1,000^{\circ} \mathrm{C}$ を超える 高温下でマグマから晶出した鉱物が凝縮したもの である。したがって，低温の水と（1気圧下で は $100^{\circ} \mathrm{C}$ 以下）接触すると非平衡状態となり, その結果，水と岩石の間で化学反応が進行し，低 温で安定な二次鉱物が生成すると同時に金属元素 が水中にイオンの形で溶出する。そうした反応を 通じて岩石表層に形成される二次鉱物が高分子有

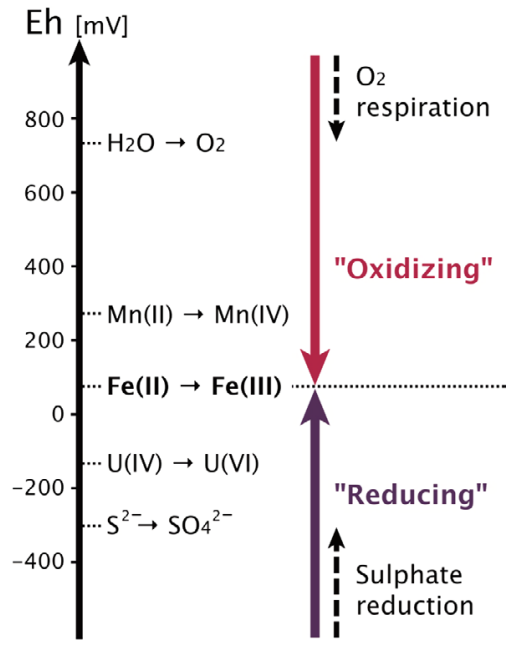

図 2 酸化還元に関わる主要な元素の酸化還元電位 (佐藤ほか, 2009)。これらの元素のなかで硫黄は もっとも酸化還元電位が低く, 価数も -2 から +6 まで幅広い価数をとることができる.

Fig. 2 Major redox sensitive elements and their redoxconditions (Sato et al., 2009). Redox conditions of sulfur are the lowest among them and it has several different electron valence conditions ranging from -2 to +6 .

機化合物のなかの活性中心に分子として組み込ま れることによって金属タンパク質が合成され，は じめて生命の化学反応が可能となる。

\section{III. 始原生命のもつ金属タンパク質}

タンパク質は， C， N， H， O , S などの軽元素 から形成されたアミノ酸が重合を繰り返すことで 形成される。しかし，それが生命としての役割を 果たすには, 非平衡状態での連続化学反応が起こ る必要があり, 細胞内で電子の流れをつくりだす 仕組みが必要である（佐藤ほか, 2019）。つまり， $\mathrm{C} ， \mathrm{~N} ， \mathrm{H} ， \mathrm{O}, \mathrm{S}$ などにより形成されたタンパク 質に，電子を多くもつ遷移金属などの金属イオン が加わることで，連続化学反応が起こる仕組みを 実現できる。表 2 は金属元素と生体中の機能ごと に金属タンパク質を分類した表である。タンパク 質全体の $30 \%$ 以上がその活性部位に 1 種類の金 属元素を含んでいる (Gray, 2003)。また酵素の およそ $40 \%$ 以上が金属を含んでいる（Bertini et 
表 2 金属タンパク質の活性部位を構成するおもな元素と金属夕ンパク質の一覧表. 生体内での機能として, 酵素と して働くものと伝達, 貯蔵として働くものとに分けて示した.

Table 2 Table of major metal elements used for the active center of metallo-protein and list of metallo-enzymes. Classification of metallo-proteins into different groups according to their functions: enzyme, transportation, and storage.

\begin{tabular}{|c|c|c|c|c|c|}
\hline \multirow{2}{*}{$\begin{array}{l}\text { Atomic } \\
\text { Num. }\end{array}$} & \multirow{2}{*}{ Elements } & \multicolumn{2}{|c|}{ Enzymes } & \multicolumn{2}{|c|}{ Transport and storage } \\
\hline & & function & name & function & name \\
\hline 12 & $\mathrm{Mg}$ & Hydroxylases & $\begin{array}{l}\text { Phosphatases } \\
\text { Aminopeptidases }\end{array}$ & & \\
\hline 23 & $\mathrm{~V}$ & Oxidoreductases & Nitrogenases & & \\
\hline 25 & $\mathrm{Mn}$ & Oxidoreductases & Superoxide dismutase & & \\
\hline \multirow[t]{4}{*}{26} & $\mathrm{Fe}$ & Oxidoreductases & $\begin{array}{l}\text { Oxidases } \\
\text { Reductases } \\
\text { Nitrogenases } \\
\text { Hydroxylases } \\
\text { Hydrogenases } \\
\text { Superoxide dismutase }\end{array}$ & & \\
\hline & & & & Electron carriers & $\begin{array}{l}\text { Cytochromes } \\
\text { Iron-sulfur proteins }\end{array}$ \\
\hline & & & & Metal management & $\begin{array}{l}\text { Ferritin } \\
\text { Transferrin }\end{array}$ \\
\hline & & & & Oxygen management & $\begin{array}{l}\text { Myoglobin } \\
\text { Hemoglobin } \\
\text { Haemerythrin }\end{array}$ \\
\hline 27 & Co & Isomerases synthetases & Vitamin B12 coenzyme & & \\
\hline 28 & $\mathrm{Ni}$ & Oxidoreductases & Hydrogenases & & \\
\hline \multirow[t]{2}{*}{29} & $\mathrm{Cu}$ & $\begin{array}{l}\text { Hydroxylases } \\
\text { Oxidoreductases }\end{array}$ & $\begin{array}{l}\text { Phosphatases } \\
\text { Oxidases } \\
\text { Reductases } \\
\text { Hydroxylases } \\
\text { Superoxide dismutase }\end{array}$ & & \\
\hline & & & & $\begin{array}{l}\text { Electron carriers } \\
\text { Metal management } \\
\text { Oxygen management }\end{array}$ & $\begin{array}{l}\text { Blue-copper proteins } \\
\text { Ceruloplasmin } \\
\text { Hemocyanin }\end{array}$ \\
\hline 30 & $\mathrm{Zn}$ & Hydroxylases & $\begin{array}{l}\text { Phosphatases } \\
\text { Aminopeptidases } \\
\text { Carboxypeptidases }\end{array}$ & & \\
\hline 42 & Mo & Oxidoreductases & $\begin{array}{l}\text { Reductases } \\
\text { Nitrogenases } \\
\text { Hydroxylases }\end{array}$ & & \\
\hline
\end{tabular}

al., 1994; Lippard and Berg, 1994; Wilson et al., 2004)。金属タンパク質は細胞中でタンパク質の 貯蔵や伝達，酵素，シグナル伝達などの多くの異 なる機能を担っている（表 2 ）。始原的な生命が もつ金属酵素にはどのようなものがあっただろうか。 Weiss ほか（2016）は，すべての生物の起源で
ある LUCA (last universal common ancestor) の機能と生息環境を推定するため, 古細菌と真正 細菌に共通する遺伝子のうち単系統で，水平伝播 が起きていないものを選び出した。それによると LUCA は水素依存で, Wood-Ljungdahl 経路を もち，窒素固定を行う嫌気性好熱菌であったとさ 
れている（Weiss et al., 2016）。したがって，始 原生命がもつ金属酵素は酸化還元電位が低く，分 子量が小さいものであったと推定される。ここで はそれらの代表例として，フェレドキシン，ヒド ロゲナーゼ，ACS/CODH 複合体について以下に 個別に説明する。

\section{1）フェレドキシン}

フェレドキシンは鉄硫黄タンパク質の 1 つで あり，2つのキュバン構造（鉄 4 元素と硫黄 4 元 素で立方体構造を形成）の $\left[\mathrm{Fe}_{4} \mathrm{~S}_{4}\right]$ 鉄硫黄クラ スターをその活性中心にもっている（図 3 )。電 子伝達物質であるフェレドキシンは，初生的な嫌 気細菌から高等植物および動物までがもつタンパ ク質で，さまざまな生化学反応，たとえば炭素固 定，窒素固定，光合成など生体内で起こる重要な 反応に電子を供給する役割を果たしている（Eck and Dayhoff, 1966)。フェレドキシンはもっとも 小さな金属タンパク質であり，分子量が 6,000 12,000，1 モルあたり $2 \sim 8$ 個の鉄と等価の硫黄 原子をもち，低い酸化還元電位（ $-300 \sim-500$ $\mathrm{mV}$ ）で電子を伝達する (Hall et al., 1971)。9 種類のアミノ酸 26 基によるポリペプチド鎖が形 成されたのち，冥王代の環境に豊富に存在した鉄 や硫化物をとり込むことで，もっとも単純なタン パク質であるフェレドキシンが形成されたと考え られている（Eck and Dayhoff, 1966; Hall et al., 1971)。

\section{2) ヒドロゲナーゼ}

ヒドロゲナーゼ（分子量：約 $91.3 \mathrm{kDa}$ ）（Ogata et $a l ., 2015)$ は，分子型水素 $\left(\mathrm{H}_{2}\right)$ の電子と陽 子への分解と，その逆反応を触媒する酵素である。

$$
\mathrm{H}_{2} \rightleftharpoons 2 \mathrm{H}^{+}+2 \mathrm{e}^{-}
$$

ヒドロゲナーゼは，微生物の細胞内で水素の分 解（酸化）と合成（プロトンの還元）を行い，細 胞内を還元的に保つ酵素である。その多くは他の 物質，たとえばフェレドキシンやチトクロム c 3 , チトクロム c6 などのタンパク質や低分子化合物 と合体して機能する。この酵素は，嫌気性代謝に おいて重要な役割を果たしており，古細菌，原核 生物，真核成分の多くの微生物がもつ代謝である
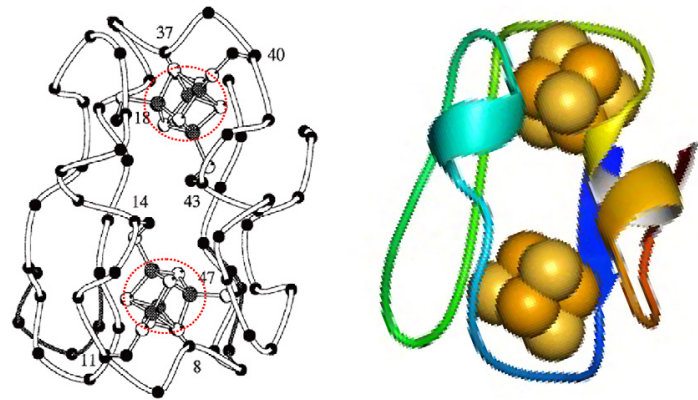

図 3 フェレドキシンの構造 (Dauter et al., 1997). 赤 丸で囲んだ部分はフェレドキシンの活性部位で 鉄 4 元素と硫黄 4 元素が立方体に結合したキュ バン構造をもつ $\left[\mathrm{Fe}_{4} \mathrm{~S}_{4}\right]$ 鉄硫黄クラスターでで きている．分子量がもっとも小さい金属タンパ ク質で，体内の重要な生化学反応に電子を供給 する役割を果たす。構造データは PDB エントリー $2 \mathrm{FDN}$ より。オレンジ色が鉄，黄色が硫黄元素を 示す.

Fig. 3 Protein fold, schematically shown as a CA coil with $\left[\mathrm{Fe}_{4} \mathrm{~S}_{4}\right]$ clusters and coordinating cysteine side chains. The second conformation of the main chain is shown in dark gray. Figure drawn with MOLSCRIPT (59) (Dauter et al., 1997). Red encircled areas are active site, $\left[\mathrm{Fe}_{4} \mathrm{~S}_{4}\right]$ clusters. Ferredoxins are small, simple proteins of fiftyfive amino-acids and have a molecular weight of 6,000 with a primitive polypeptide structure. They act as electron carriers in a range of metabolic reactions. Structure data taken from PDB entry 2FND. Orange and yellow balls are iron and sulfur, respectively.

(Vignais and Billoud, 2007)。ヒドロゲナーゼ は，その活性中心の構造の違いにより， $[\mathrm{NiFe}]$ ヒドロゲナーゼ， $[\mathrm{FeFe}]$ ヒドロゲナーゼ， $[\mathrm{Fe}]$ ヒドロゲナーゼの 3 種類がある（Vignais and Billoud, 2007; Fontecilla-Camps et al., 2009)。 [Fe] ヒドロゲナーゼは，以前はメタルフリーヒ ドロゲナーゼとされていたが Lyon et al.（2004） により鉄を含むことが報告された。この酵素は $\mathrm{Ni}$ の少ない特殊な環境に生息するメタン生成菌 のみにみられるものである。 $[\mathrm{NiFe}]$ ヒドロゲナー ゼと $[\mathrm{FeFe}]$ ヒドロゲナーゼには構造的に多く の共通点がある。どちらの酵素も 1 つの活性部 とタンパク質中に数個の鉄硫黄クラスターをもつ。 触媒反応が起こる活性中心は，金属クラスターで 


\section{[NiFe] Hydrogenase}
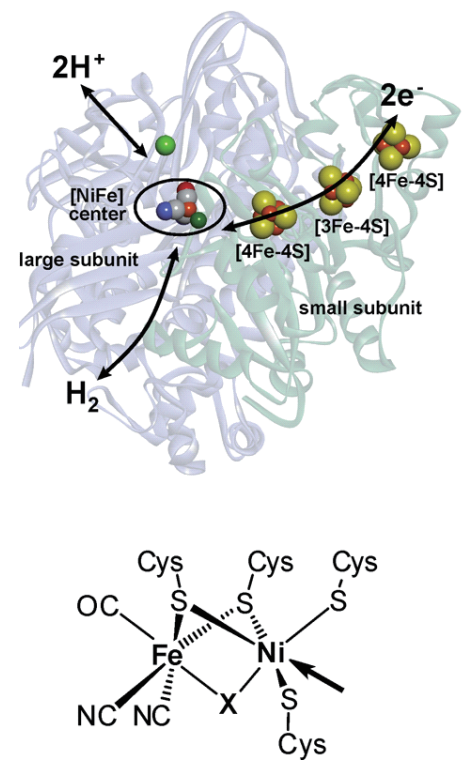

\section{[FeFe] Hydrogenase}
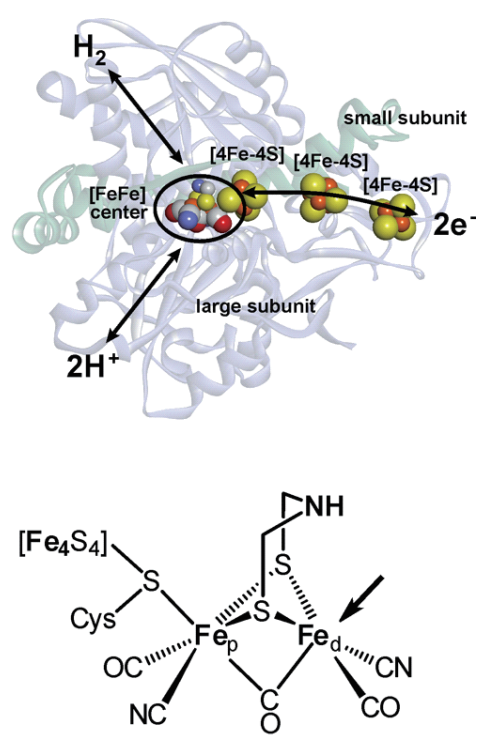

図 $4[\mathrm{FeFe}],[\mathrm{FeNi}]$ ヒドロゲナーゼの結晶構造とそれぞれの活性部位 (Lubitz et al., 2014). ヒドロゲナーゼは, 微生物の細胞内で水素の分解（酸化）と合成（プロトンの還元）を行なう酵素である. その活性中心の構造の違 いにより，[NiFe] ヒドロゲナーゼ, $[\mathrm{FeFe}]$ ヒドロゲナーゼ，[Fe] ヒドロゲナーゼの 3 種類があることが知ら れている.

Fig. 4 Crystal structures of $[\mathrm{FeFe}]$ and $[\mathrm{NiFe}]$ hydrogenases and their active centers (Lubitz et al., 2014). Hydrogenases catalyze one of the simplest molecular reactions, the conversion of dihydrogen into protons and electrons and the reverse reaction. They can be classified according to the metal ion composition of their active sites in $[\mathrm{NiFe}],[\mathrm{FeFe}]$, and $[\mathrm{Fe}]$ hydrogenases.

構成されており，各金属に $\mathrm{CO}$ と $\mathrm{CN}$-リガンド が配位している。また，タンパク質中に電子を伝 達するために 3 個の $\left[\mathrm{Fe}_{4} \mathrm{~S}_{4}\right]$ 鉄硫黄クラスター ([NiFe] ヒドロゲナーゼの場合, 真ん中の鉄硫 黄クラスターは $\left.\left[\mathrm{Fe}_{3} \mathrm{~S}_{4}\right]\right)$ の構造をもっている (図 4 )。

\section{3) ACS/CODH 複合体}

ACS/CODH 複合体 (310 kDa: Moorella Thermoacetica (Darnault et al., 2003)) は，二酸化 炭素を唯一の炭素源としている独立化学合成細 菌のもつ炭素固定回路のうち，もっとも始原的 な回路の 1 つを構成している。これは WoodLjungdahl pathway 中に存在する酵素の 1 つで ある (Ljungdahl, 1986)。2000 年以降急速に発 達した複雑なタンパク質の構造解析技術により, この酵素の構造が解明されている。 $\mathrm{ACS} / \mathrm{CODH}$
は二量体を形成しており, 中央に 2 つ $\mathrm{CODH}$, 両端にACS がそれぞれ配置する（Darnault et al., 2003; Matsumoto, 2009)（図 5A)。ACSに は A-cluster, CODH には B-, C-, D-cluster と よばれる鉄硫黄クラスターがその活性中心にある。 ACS の活性中心 A-cluster はキュバン構造をもつ $\left[\mathrm{Fe}_{4} \mathrm{~S}_{4}\right]$ と平面 4 配位構造のニッケルから構成さ れている (Svetlitchnyi et al., 2004) (図 5B)。 $\mathrm{CODH}$ の活性中心である B-, C-, D-cluster のう ち, B-cluster と D-cluster は ACS の活性中心に A-cluster と同様のキュバン構造をもつ $\left[\mathrm{Fe}_{4} \mathrm{~S}_{4}\right]$ クラスターからなる。C-cluster はニッケルを含 む不完全なキュバン構造で $\left[\mathrm{Fe}_{3} \mathrm{~S}_{4}\right]$ を形成して いる（図 5C)。C-cluster での酸化還元反応によっ て生成された電子は B, D-cluster を通してタン パク質に伝達される。 


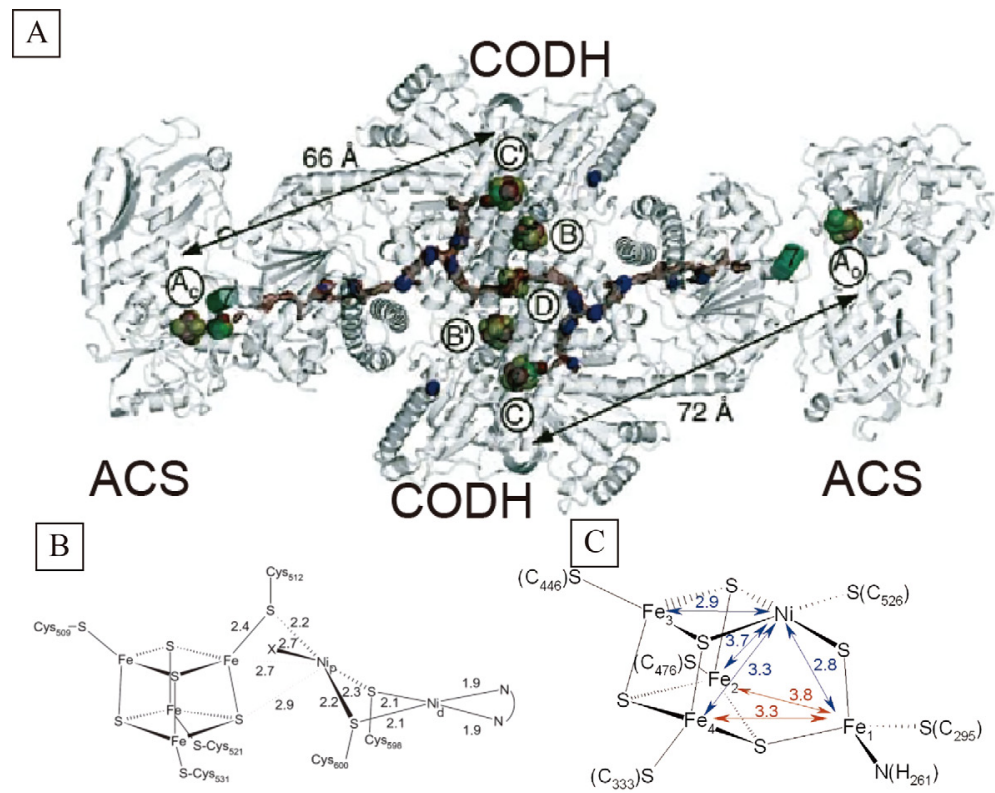

図 5 (A) ACS/CODH 複合体の立体構造 (Darnault et al., 2003). ACS は，二酸化炭素と一酸化炭素の可逆的な反応 を触媒する CO デヒドロゲナーゼと複合体を形成する。 ACS/CODH 複合体は二量体を形成し，中央にCODH 2 つと両端にACSが存在している。（B）ACSのA-clusterの活性部位の詳細構造（Svetlitchnyi et al., 2004）。(C) CODH $の$ C-cluster の活性部位の詳細構造（Dobbeck et al., 2001）.

Fig. 5 (A) Crystal structure of ACS/CODH complex (Darnault et al., 2003). ACS forms a bifunctional enzyme with Carbon monoxide dehydrogenase $(\mathrm{CODH})$, which converts carbon dioxide into carbon monoxide, Acetyl-CoA Synthase/Carbon Monoxide Dehydrogenase (ACS/CODH). The structure of the CODH/ACS enzyme consists of the CODH enzyme as a dimer at the center with two ACS subunits at each side. (B) Structure of A-cluster (Svetlitchnyi et al., 2004). (C) Structure of C-cluster (Dobbek et al., 2001).

4）鉱物と金属タンパク質の関係および本研究 の目的

このようにもっとも始原的といわれ，生命の起 源に深くかかわったと思われる金属タンパク質に は共通して $\left[\mathrm{Fe}_{4} \mathrm{~S}_{4}\right]$ 鉄硫黄クラスターが含まれ ている。生命にとって重要なこれらの鉄硫黄ク ラスターは初期地球に存在した硫化鉄 $(\mathrm{FeS})$ か らもたらされたのではないかという発想は 50 年 以上前から提案されていた (Eck and Dayhoff, 1966)。また, 熱水噴出孔での Iron-Sulfur Membrane 仮説を提唱している Russell らのグ ループも, 熱水噴出孔に硫化物が多くみられるこ と, 硫化物のなかでも逆スピネル構造をもつグレ イガイトはこの $\left[\mathrm{Fe}_{4} \mathrm{~S}_{4}\right]$ 鉄硫黄クラスターとよ く似た構造をもっていることから, 初期地球で合 成されたペプチドがグレイガイトのもつ $\left[\mathrm{Fe}_{4} \mathrm{~S}_{4}\right]$
鉄硫黄クラスターをとり込んで始原的な金属夕ン パク質が形成されたのではないかと指摘してい る (Russell and Hall, 1997, 2006; Russell and Martin, 2004 ほか)。Russell らのグループの最 近の研究によると, 各硫化鉱物と金属タンパク の活性部位との構造の類似性から（1） Ni-Fe ヒ ドロゲナーゼはニッケルマッキナワイト， $(2)$ CODH C cluster は Ni-グレイガイト，（3） ACS の A-クラスターはヴァイオラライトから形成さ れた酵素であろうと対応づけている（Nitschke et al., 2013; Russell et al., 2014; 図 6 )。

しかしながら，彼らはマッキナワイト以外の鉱 物が熱水噴出孔のマウンドから見つかっているか どうかは明言していない。これまでの研究では, 金属タンパク酵素と硫化鉱物などの鉱物との構造 の類似性は指摘されていたが，生命誕生場に存在 


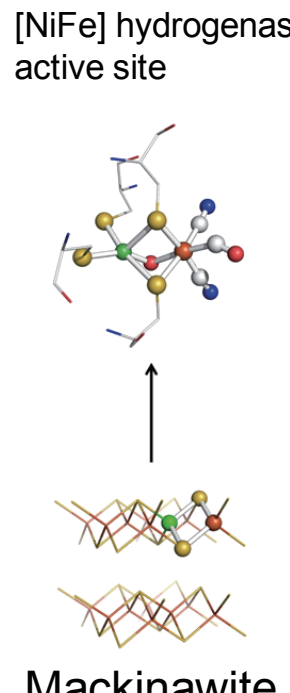

Mackinawite

\section{$\mathrm{CODH}$ C- cluster}

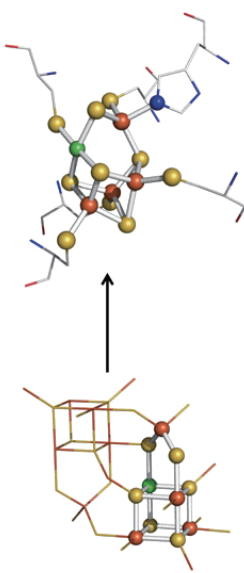

Greigite
ACS active site A-cluster
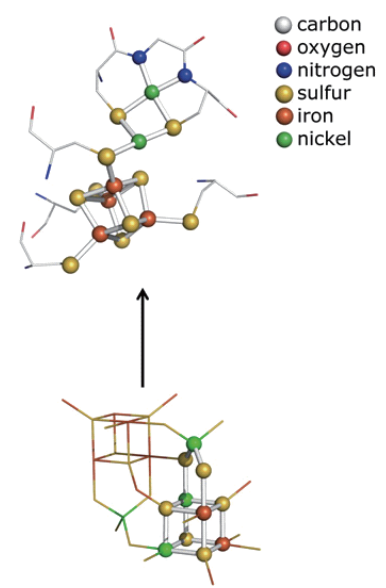

Violarite

図 6 金属夕ンパク質と鉱物との構造の類似性による対応. [NiFe] ヒドロゲナーゼの活性部位はマッキナワイトの結 晶構造，CO デヒドロゲナーゼの C-cluster は Greigite, ACS の活性部位の A-cluster は Violarite とそれぞれ対応 している (Nitschke et al., 2013; Russell et al., 2014).

Fig. 6 Diagram demonstrating affinities between natural sulfide nickelian mackinawite, greigite, and violarite with the active centers of early the metalloenzymes above: Ni-Fe hydrogenase, CO dehydrogenase (CODH), and acetyl coenzyme-A synthase (active site or A cluster, ACS) respectively (Nitschke et al., 2013; Russell et al., 2014).

した岩石と明示的に関連付けた研究は行われてい なかった。本研究では，まず，冥王代のモダンア ナログである白馬八方地域で採取した蛇紋岩に含 まれる金属鉱物を分離し，始原生命のもつ金属夕 ンパク質の形成につながる鉱物の存在を検証し た。次に，冥王代表層環境に存在していたと考え られるその他の岩石である KREEP 立武岩およ びアノーソサイトについて，熱水変質が起きたと きの溶液組成と金属鉱物が生成する可能性を熱力 学計算により検討し，冥王代の生命誕生場の岩石 としてのポテンシャルを評価した。

\section{IV. 岩石-水相互作用とそれに伴って形成される 二次鉱物}

II 章 1)節で述べたように，冥王代地球の表層 環境では，おもに 3 種類の岩石（アノーソサイ ト，コマチアイト，KREEP 玄武岩）が卓越して いた。それぞれの岩石の化学組成が異なるため に，溶けだす金属元素が異なる。そうした金属元
素の差が，合成される有機物の金属クラスターの 違いの原因となったと考えられる。冥王代の岩石 は現在の地球上に現存していないが，コマチアイ トについては，冥王代類似環境・白馬八方蛇紋岩 体の蛇紋岩を用いて，岩石学的な検討が可能であ る。アノーソサイトおよび KREEP 玄武岩の類 似岩石としては，月の表層の岩石が考えられる。 本研究では，アポロ試料の記載およびかぐやの観 測データをもとに，熱力学計算により変質二次鉱 物と共存する溶液の組成，および金属鉱物の安定 性を議論する。

1）コマチアイト質火山・深成岩類の二次変質 と変質鉱物

現在の地球に存在する冥王代類似環境の 1 つ が白馬八方蛇紋岩熱水系である。本節では，現在 の水素発生場である白馬八方温泉の母岩である蛇 紋岩（図 7 の巨大なカンラン岩）から採取した 2 試料（試料番号 $2 ， 3 \mathrm{~A}$ ）に対して，偏光顕微鏡 による薄片観察と SEM-EDS を用いて蛇紋岩化 
(a)
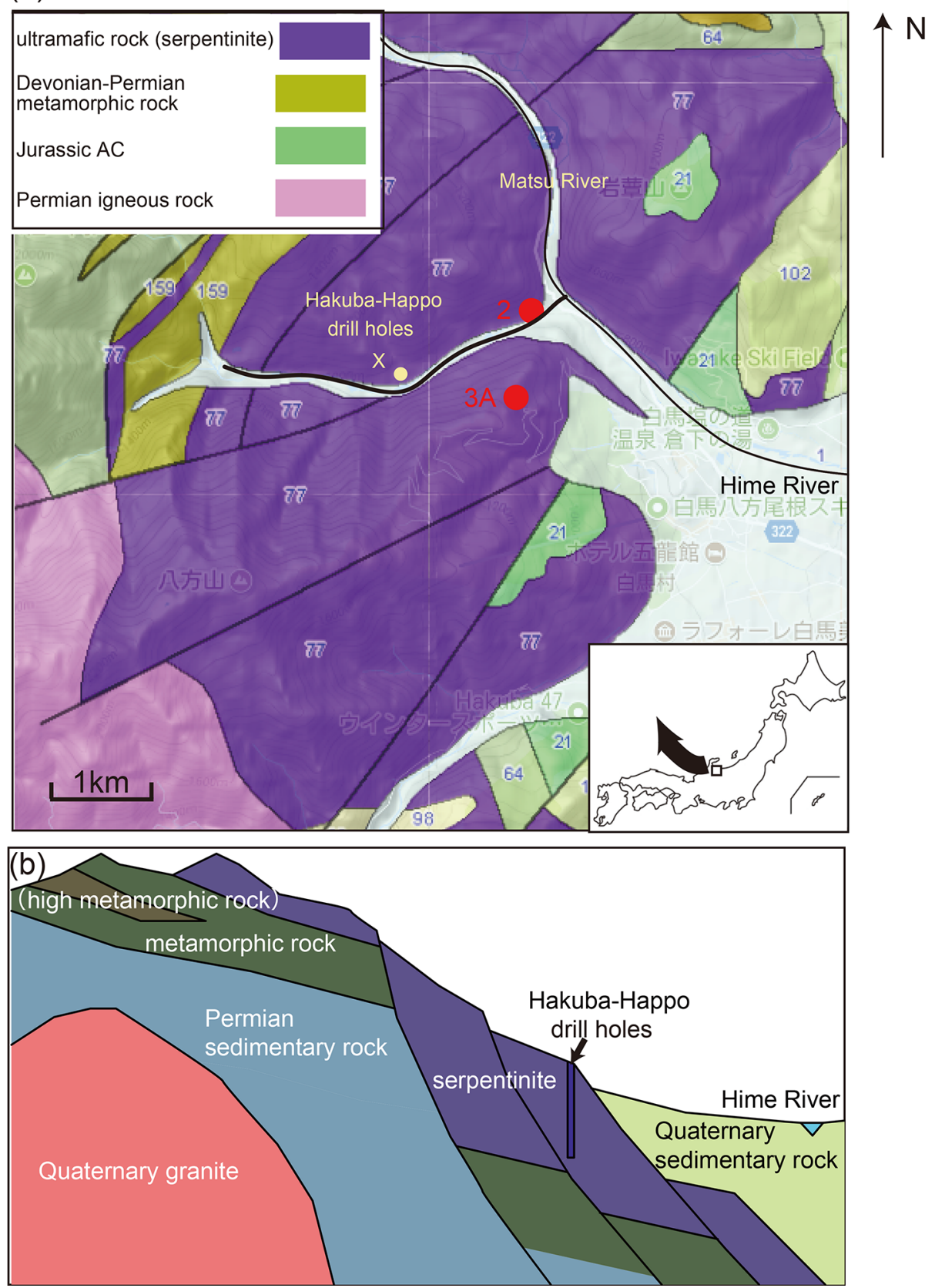

図 7 (a) 白馬地域の地質図と白馬八方温泉熱水系の模式断面図（産業技術総合研究所地質調査総合センター, 2015 を 改変). 赤い丸の地点が今回の試料採取場所. (b) 白馬地域の断面図. 白馬最大の蛇紋岩岩体上に深さ約 $700 \mathrm{~m}$ の掘削井戸があり，温泉を地下から引き上げている. Hakuba OD1はこの井戸から発見された.

Fig. 7 (a) Geologic map of Hakuba area and schematic cross-section showing the Hakuba-Happo hydrothermal system (modified from AIST, 2015). Red dots are locations where samples were collected. (b) Geological cross-section of the area. Approximately 700-m deep drilling holes are located on the largest serpentinite block, and underground hot-water is pumped up from them. Hakuba OD1 was found from hot spring water deep underground. 
作用によって生成した二次変質鉱物を観察し，始 原生命のもつ代謝との関連性を議論する。

\section{1-1）長野県北部白馬地域の地質概要}

白馬地域のなかで最大のカンラン岩蛇紋岩体は ダナイトが主体を占める。カンラン岩体は強いせ ん断変形を受けて $80 \mathrm{wt} \%$ 以上蛇紋岩化している が，約 $10 \mathrm{~km} \times 10 \mathrm{~km}$ サイズに引きちぎられた 複数のブーダン状ダナイト岩帯が残存している。 露頭スケールでも数 $\mathrm{m}$ から数 $\mathrm{cm}$ 長の規模の夕゙ ナイトブーダンがみられる。せん断面の構造は北 西縁の結晶片岩の片理と平行である。超塩基性岩 の再結晶作用とともに，トレモライトなどを含む 二次鉱物の組み合わせで 2 つのゾーンに区別され る（Nakamizu et al., 1989）。実線（トレモライ トの出現反応）の東側が低温側で採取試料（2,

3A）は低温領域にある。

地点 X は掘削井戸のサイトで，700 $\mathrm{m}$ 深部に 達する掘削井戸で，冥王代類似環境微生物であ る Hakuba OD1はこの井戸から発見された（戎 崎ほか, in press)。Hakuba OD1は，分子系統 学的にきわめて古いことが明らかにされており, 最初期の炭素固定反応である Wood-Ljungdahl pathwayをもつのではないかと推定されている（戎 崎ほか, in press)。

白馬カンラン岩体は 6 億年前（酸素が急増す る以前）に付加した海洋プレートの一部である。 この岩体は太平洋型造山帯にトラップされた後, 造山帯のなかを循環する流体によって水素発生を 続け，超還元場を継続してきたと考えられる（佐 藤ほか, 2019)。

\section{1-2）蛇紋岩試料の顕微鏡観察}

採取した 2 試料について顕微鏡観察を行った。 試料 2 と試料 $3 \mathrm{~A}$ では蛇紋岩化の進行度に違いが みられる。試料 2 はカンラン石がメッシュ状の 蛇紋石の間に鱗片状のカンラン岩が残っている。 全体の拈よそ $35 \%$ をカンラン石の残晶が占める。 それに対して試料 $3 \mathrm{~A}$ では, 残晶カンラン石はわ ずかにしかみられず，蛇紋石がほとんどを占めて おり, 蛇紋岩化が $95 \%$ 以上進んでいる。蛇紋石 類のうち，アンチゴライトが $90 \%$ で，リザーダ イトは約 $10 \%$ であ。試料は新鮮でクリソ夕イ
ルはほとんどみられない。

図 8 に示すような比較的大きく明瞭なカンラ ン石（forsterite）の残晶 $\left(\mathrm{Fo}_{0}=9 \mathrm{x}\right)$ は薄片中で 2 か所認められた。不明瞭な残骸は数か所観察さ れ，蛇紋岩化作用により，カンラン石が蛇紋石や クリノクロアと磁鉄鉱に変化したことは組織か ら明らかである（図 9 )。SEM-EDS を使って， この磁鉄鉱の部分を拡大してみると組成の違いか ら，2 種類の鉱物, 磁鉄鉱と $\mathrm{Fe} \mathrm{Ni}$ 硫化物 (ペン トランダイト $\left.(\mathrm{Fe}, \mathrm{Ni})_{9} \mathrm{~S}_{8}\right)$ で構成されている ことがわかった。 Ni の起源は, カンラン石に少 量含まれていたマグマ起源の Ni である。

2) KREEP 玄武岩，アノーソサイト，および 始源的上部マントルカンラン岩の岩石-水 反応

冥王代当時，地球表層を覆っていたとされる KREEP 玄武岩とアノーソサイトは，該当する岩 石が現存しておらず，モダンアナログに対応する 岩石も存在しない。しかし，月の表層には冥王代 の地球上に存在したと考えられる岩石が残されて いる。月は形成後マグマオーシャンがすぐに固化 し, 活動が停止したためである。本研究ではアポ 口計画で採取された月の石の岩石・鉱物学研究を 参考にして，熱力学計算によって变質鉱物と溶液 組成を推定することとした。また，溶液組成の 比較のために，始源的上部マントルカンラン岩 のモデル組成においても同様の計算を行った。

KREEP 玄武岩は，鉄とチタンに富む mare basalt 74220 (orange glass) の全岩成分（Rhodes et al., 1974; Wänke et al., 1973; 図 10A）を用い, その 成分からモード計算により鉱物組成を決定した (図 10A)。アノーソサイトについては，かぐや の観測結果（Ohtake et al., 2009）を参考に，純 粋なアノーソサイト Purest Anorthosite $=$ PAN ( $100 \%$ Ca-rich Plagioclase 化学式: $\mathrm{CaAl}_{2} \mathrm{Si}_{2} \mathrm{O}_{8}$ ) を想定した。上部マントルカンラン岩のモデル組 成には，McDonough and Sun（1995）の值を用 いた。それらの岩石組成をもとに岩石 $100 \mathrm{~g}$ に対 して, 水 $500 \mathrm{~g}$ を加え, 1 気圧, 温度 $0 \sim 95^{\circ} \mathrm{C}$ で反応させた場合に生成する主要変質鉱物と水溶 液の組成を熱力学計算により求めた（図 10B）。 


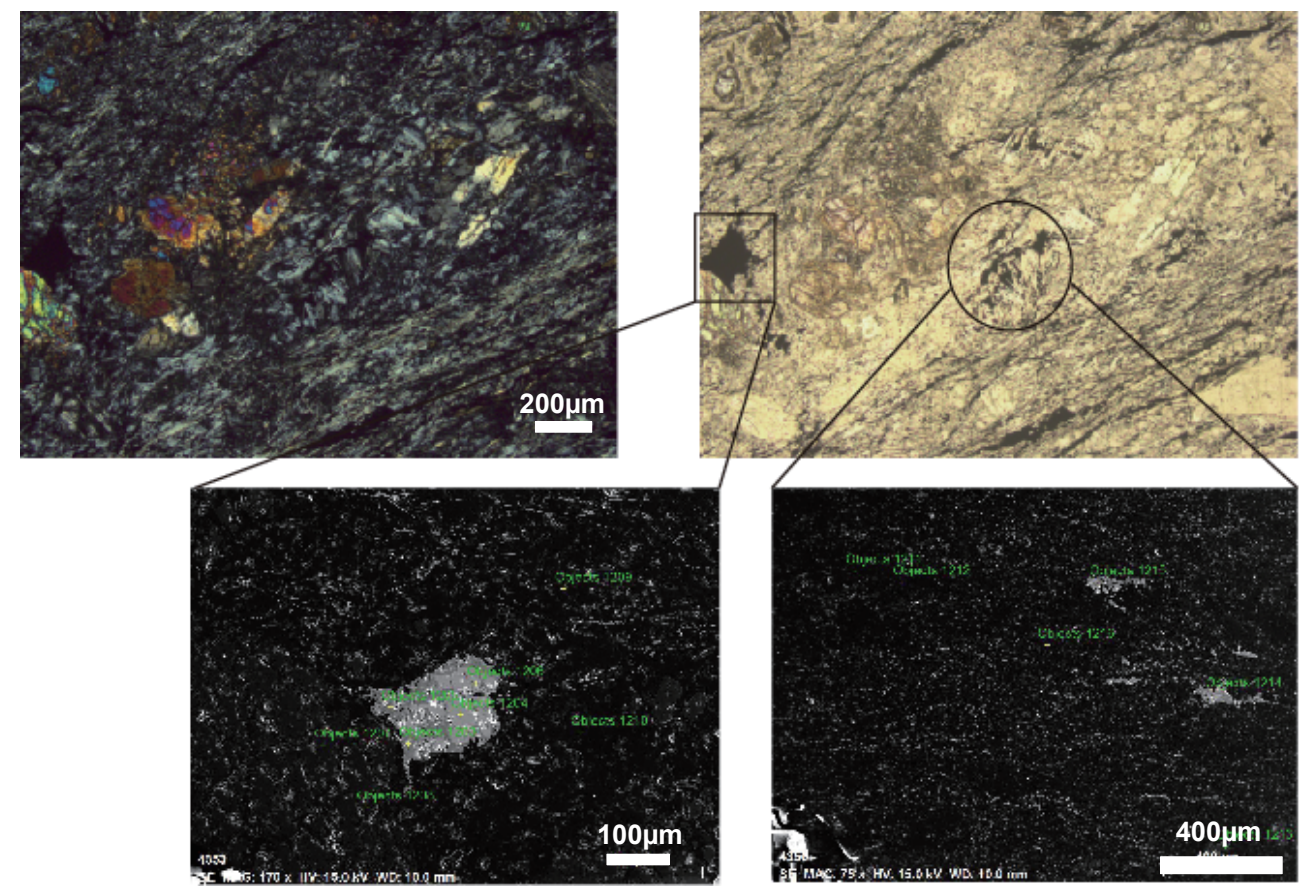

図 8 (上) 試料 2 の薄片の顕微鏡写真. 蛇紋岩化作用により, カンラン石が蛇紋石と不透明鉱物が形成されている.

(下） 2 か所の不透明鉱物を拡大した SEM の SE 像. この不透明鉱物は磁鉄鉱とニッケル硫化物（ペントランダ イト）の離溶ラメラとなっている. 明るいグレーの部分がペントランダイトで, 濃いグレーの部分が磁鉄鉱である.

Fig. 8 (upper) Microphotos (Photo to the left is cross-polarized; photo to the right is open nicole) of a thin section of sample No. 2. Olivine affected by a water rock reaction to form serpentine and an opaque mineral. (lower) Enlarged SE image of two parts of opaque mineral. They consist of magnetite and pentlandite exsolution lamellae. Light grey area is pentlandite and dark grey area is magnetite.

使用したプログラムは GEM-Selektor v.3 (GEMS3)（Kulik et al., 2013）で，与えられた 岩石 + 水の化学組成において平衡な溶存種濃度 を, Gibbs エネルギー最小化法により求めている。 熱力学データセットには SUPCRT92 を使用した (Johnson et al., 1992)。

KREEP 玄武岩から形成されるおもな二次鉱物 は赤鉄鉱，チタン石，滑石であり，その他にカ才 リナイト，ローモンタイトなどの $\mathrm{Al}$ や $\mathrm{Ca}$ を多 く含む変成鉱物が生成する。純粋なアノーソサイ 卜の岩石水反応によって生成する二次鉱物はギブ ス石，ブドウ石，カオリナイトの組み合わせで, $\mathrm{Al}$ と $\mathrm{Ca}$ の水酸化鉱物が生成する。

各岩石と反応した後の水溶液中の代表的なイ オン濃度を図 11 に示した。イオン濃度は，全岩
組成濃度をほぼ反映している。 $\mathrm{PO}_{4}{ }^{3-}$ 濃度は, KREEP 立武岩がカンラン岩に比べて 5 桁以上高 い。また, $\mathrm{pH}$ は, カンラン岩でもっとも高く, PAN，KREEP 玄武岩の順で低くなる。しかし， その幅は 0.5 程度であり, アルカリ溶液環境は, PAN や KREEP 立武岩においても形成され得る ことが示されている。

\section{V. 議論}

\section{1）蛇紋岩化反応による二次変質鉱物と金属夕 ンパク質の関係}

1-1）蛇紋岩化反応により生成した二次変質鉱物 超苦鉄質岩が水と反応することで起こる蛇紋岩 化反応によって，どのような化学変化が起こり， 二次変質鉱物が生じるのかをまとめる。超塩基性 

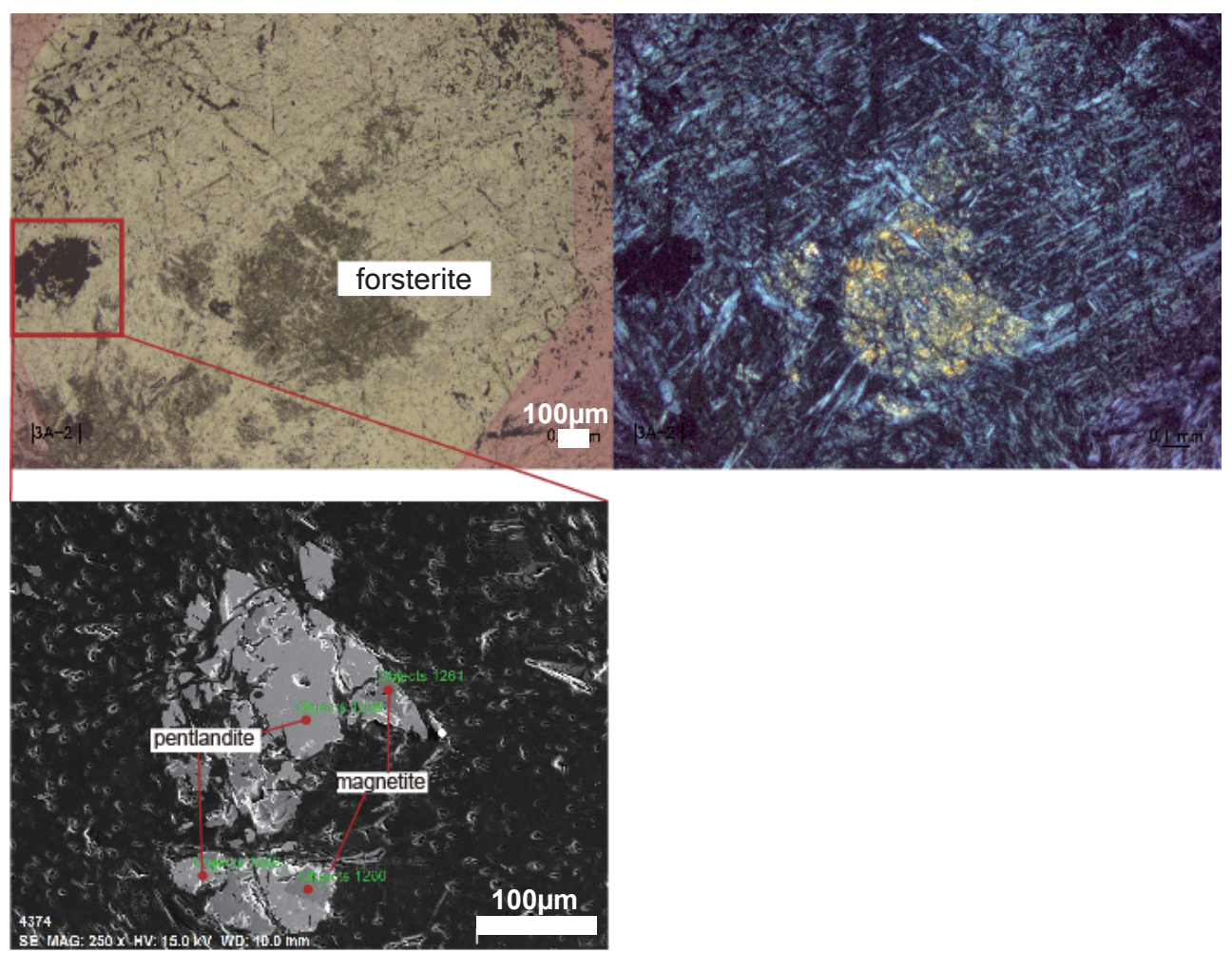

図 9 (上) 試料 $3 \mathrm{~A}$ でカンラン石 (forsterite) が残っている部分の顕微鏡写真 (左:オープンニコル, 右:クロスニコル). （下）不透明鉱物を拡大した SEM の SE 像. ペントランダイト $\left((\mathrm{Ni}, \mathrm{Fe}){ }_{9} \mathrm{~S}_{8}\right)$ と磁鉄鉱の離溶ラメラ. 明るいグレー の部分がペントランダイトで，濃いグレーの部分が磁鉄鉱.

Fig. 9 (upper) Microphotos (Photo to the left is open nicole photo; photo to the right is cross-polarized) of a thin section of sample No. 3A. Large forsterite relict observed. (lower) Enlarged SE image of opaque mineral. It consists of magnetite and pentlandite exsolution lamellae. Light grey area is pentlandite and dark grey area is magnetite.

岩であるコマチアイトの主要鉱物はカンラン石 (モードで約 $60 \%$ ) であり，カンラン石のうち, fayalite $(\mathrm{Fa}$ : 鉄カンラン石) が水と反応すると 水素が発生する (式 2)。

$$
\begin{aligned}
& 6 \mathrm{Fe}_{2} \mathrm{SiO}_{4}+7 \mathrm{H}_{2} \mathrm{O} \\
& \quad \mathrm{Fa} \text { in olivine } \\
& =\underset{2}{3 \mathrm{Fe}_{3} \mathrm{Si}_{2} \mathrm{O}_{5}(\mathrm{OH})_{4}}+\mathrm{Fe}_{3} \mathrm{O}_{4}+\mathrm{H}_{2} \\
& \quad \mathrm{Fe} \text {-serpentinite magnetite }
\end{aligned}
$$

この反応によって局所的に超還元環境が形成さ れる（Frost, 1985）。注意しておきたいのは，こ の反応は非平衡反応だということである。カン ラン石 $+\mathrm{H}_{2} \mathrm{O}$ の組み合わせは，たとえば $500 \mathrm{bar}$ では $350^{\circ} \mathrm{C}$ 以上の場合に理論上は熱力学的に安
定で，それ以下の温度ではカンラン石は安定でな く，代わって蛇紋石とブルーサイトが安定となる。 熱水変質は高温状態から徐々に温度が下がって反 応曲線を横切って進行するのではなく, カンラン 石 $+\mathrm{H}_{2} \mathrm{O}$ が不安定な低温の条件で水が浸入して 反応が進行する。

式 2 によって蛇紋石が岩石中で二次鉱物とし て生成される作用を蛇紋岩化作用とよぶ。カンラ ン石が蛇紋石になった後も，水との反応を続ける

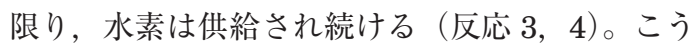
して形成された還元環境は，アミノ酸を合成する 過程において非常に重要である（Sakata et al., 2014; Rodriguez-Garcia et al., 2015)。 
A KREEP basalt

Whole rock composition of the 74220 (orange glass) Results of CIPW norm calcuration

\begin{tabular}{|c|c|}
\hline & weight $\%$ \\
\hline $\mathrm{SiO}_{2}$ & 38.57 \\
\hline $\mathrm{TiO}_{2}$ & 8.81 \\
\hline $\mathrm{Al}_{2} \mathrm{O}_{3}$ & 6.32 \\
\hline $\mathrm{FeO}$ & 22.04 \\
\hline $\mathrm{MnO}$ & 0.3 \\
\hline $\mathrm{MgO}$ & 14.44 \\
\hline $\mathrm{CaO}$ & 7.68 \\
\hline $\mathrm{Na}_{2} \mathrm{O}$ & 0.36 \\
\hline $\mathrm{K}_{2} \mathrm{O}$ & 0.09 \\
\hline $\mathrm{P}_{2} \mathrm{O}_{5}$ & 0.04 \\
\hline$S$ & 0.07 \\
\hline \multirow[t]{2}{*}{ Reference } & Rhodes et al., 1974 \\
\hline & ppm \\
\hline $\mathrm{Sc}$ & 42.5 \\
\hline $\mathrm{V}$ & 130 \\
\hline $\mathrm{Cr}$ & 4030 \\
\hline $\mathrm{Co}$ & 55.5 \\
\hline $\mathrm{Ni}$ & 67 \\
\hline $\mathrm{Cu}$ & 25 \\
\hline $\mathrm{Zn}$ & 270 \\
\hline $\mathrm{Ga}$ & 16.5 \\
\hline Reference & Wanke et al., 1973 \\
\hline
\end{tabular}

\begin{tabular}{|l|l|l|r|}
\hline & Minerals & chemical formula & wt\% \\
\hline Major & & & \\
\hline & olivine & $2(\mathrm{Mg}, \mathrm{Fe}) \mathrm{O} \cdot \mathrm{SiO}_{2}$ & 40.68 \\
\hline & diopside & $\mathrm{CaO} \cdot(\mathrm{Mg}, \mathrm{Fe}) \mathrm{O} \cdot 2 \mathrm{SiO}_{2}$ & 19.27 \\
\hline & anorthite & $\mathrm{CaO} \cdot \mathrm{Al}_{2} \mathrm{O}_{3} \cdot 2 \mathrm{SiO}_{2}$ & 16.07 \\
\hline & albite & $\mathrm{Na}_{2} \mathrm{O} \cdot \mathrm{Al}_{2} \mathrm{O}_{3} \cdot 6 \mathrm{SiO}_{2}$ & 3.19 \\
\hline & hypersthene & $(\mathrm{Mg}, \mathrm{Fe}) \mathrm{O} \cdot \mathrm{SiO}_{2}$ & 1.24 \\
\hline & orthoclase & $\mathrm{K}_{2} \mathrm{O} \cdot \mathrm{Al}_{2} \mathrm{O}_{3} \cdot 6 \mathrm{SiO}_{2}$ & 0.56 \\
\hline Minor & & & \\
\hline & ilmenite & $\mathrm{FeO} \cdot \mathrm{TiO}_{2}$ & 17.51 \\
\hline & chromite & $\mathrm{FeO} \cdot \mathrm{Cr}_{2} \mathrm{O}_{3}$ & 0.91 \\
\hline & apatite & $3\left(3 \mathrm{CaO} \cdot \mathrm{P}_{2} \mathrm{O}_{5}\right) \mathrm{CaF}_{2}$ & 0.30 \\
\hline & pyrite & $\mathrm{FeS}$ & 0.27 \\
\hline
\end{tabular}

$\mathrm{B}$

Purest Anorthosite $(100 \mathrm{~g})+$ water $(500 \mathrm{~g})$

\begin{tabular}{|l|l|c|c|c|c|c|c|c|c|}
\hline condition & temperature $\left({ }^{\circ} \mathrm{C}\right)$ & 0 & 5 & 25 & 50 & 75 & 95 & 100 \\
\hline \multirow{2}{*}{$\begin{array}{l}\text { secondary } \\
\text { minerals }\end{array}$} & Gibbsite & $\mathrm{Al}(\mathrm{OH})_{3}$ & & & & & & & \\
\cline { 2 - 9 } & Prehnite & $\mathrm{Ca}_{2} \mathrm{Al}\left(\mathrm{AlSi}_{3} \mathrm{O}_{10}\right)(\mathrm{OH})_{2}$ & & & & & & & \\
\cline { 2 - 7 } & Kaolinite & $\mathrm{Al}_{4} \mathrm{Si}_{4} \mathrm{O}_{10}(\mathrm{OH})_{8}$ & & & & & & & \\
\hline
\end{tabular}

KREEP basalt $(100 \mathrm{~g})+$ water $(500 \mathrm{~g})$

\begin{tabular}{|c|c|c|c|c|c|c|c|c|c|}
\hline condition & \multicolumn{2}{|c|}{ temperature $\left({ }^{\circ} \mathrm{C}\right)$} & 0 & 5 & 25 & 50 & 75 & 95 & 100 \\
\hline \multirow{14}{*}{$\begin{array}{l}\text { secondary } \\
\text { minerals }\end{array}$} & Gibbsite & $\mathrm{Al}(\mathrm{OH})_{3}$ & & & & & & & \\
\hline & Kaolinite & $\mathrm{Al}_{4} \mathrm{Si}_{4} \mathrm{O}_{10}(\mathrm{OH})_{8}$ & & & & & & & \\
\hline & Prehnite & $\mathrm{Ca}_{2} \mathrm{Al}\left(\mathrm{AlSi}_{3} \mathrm{O}_{10}\right)(\mathrm{OH})_{2}$ & & & & & & & \\
\hline & Andradite & $\mathrm{Ca}_{3} \mathrm{Fe}_{2}^{3+}\left(\mathrm{SiO}_{4}\right)_{3}$ & & & & & & & \\
\hline & Epidote & $\mathrm{Ca}_{2} \mathrm{Fe}^{3+} \mathrm{Al}_{2}\left(\mathrm{Si}_{2} \mathrm{O}_{7}\right)\left(\mathrm{SiO}_{4}\right) \mathrm{O}(\mathrm{OH})$ & & & & & & & \\
\hline & Anhydrite & $\mathrm{CaSO}_{4}$ & & & & & & & \\
\hline & Titanite & $\mathrm{CaTiSiO}_{5}$ & & & & & & & \\
\hline & Laumontite & $\mathrm{Ca}\left(\mathrm{AlSi}_{2} \mathrm{O}_{6}\right)_{2} \cdot 4 \mathrm{H}_{2} \mathrm{O}$ & & & & & & & \\
\hline & Hematite & $\mathrm{Fe}_{2} \mathrm{O}_{3}$ & & & & & & & \\
\hline & Muscovite & $\mathrm{KAl}_{2}\left(\mathrm{AlSi}_{3}\right) \mathrm{O}_{10}(\mathrm{OH})_{2}$ & & & & & & & \\
\hline & Phlogopite & $\mathrm{KMg}_{3} \mathrm{AlSi}_{3} \mathrm{O}_{10}(\mathrm{OH}, \mathrm{F})_{2}$ & & & & & & & \\
\hline & Clinochlore & $(\mathrm{Mg}, \mathrm{Fe})_{5} \mathrm{Al}\left(\mathrm{Si} \mathrm{Al} \mathrm{O} \mathrm{O}_{10}(\mathrm{OH})_{8}\right.$ & & & & & & & \\
\hline & Talc & $\mathrm{Mg}_{3} \mathrm{Si}_{4} \mathrm{O}_{10}(\mathrm{OH})_{2}$ & & & & & & & \\
\hline & Paragonit & $=\mathrm{NaAl}_{2}\left(\mathrm{Si}_{3} \mathrm{Al}\right) \mathrm{O}_{10}(\mathrm{OH})_{2}$ & & & & & & & \\
\hline
\end{tabular}

図 10 （A）月の KREEP玄武岩（74220 orange glass）の全岩組成（Rhodes et al., 1974; Wänke et al., 1973）とノルム計 算によって得られた鉱物組成。（B）純粋なアノーソサイト（100 g ）とKREEP玄武岩（100 g）をそれぞれ $500 \mathrm{~g}$ の水で反応させた場合に生成する鉱物を熱力学計算で求めた.

Fig. 10 (A) Whole rock composition of moon KREEP basalt (74220 orange glass) (Rhodes et al., 1974; Wänke et al., 1973). Estimated mineral compositions of 74220 using a norm calculation. (B) A thermo-dynamic calculation is used to estimate minerals obtained from a water rock reaction of $100 \mathrm{~g}$ of KREEP basalt (74220 orange glass) collected from the moon surface and $100 \mathrm{~g}$ of purest anorthosite react with $500 \mathrm{~g}$ of water, respectively. 

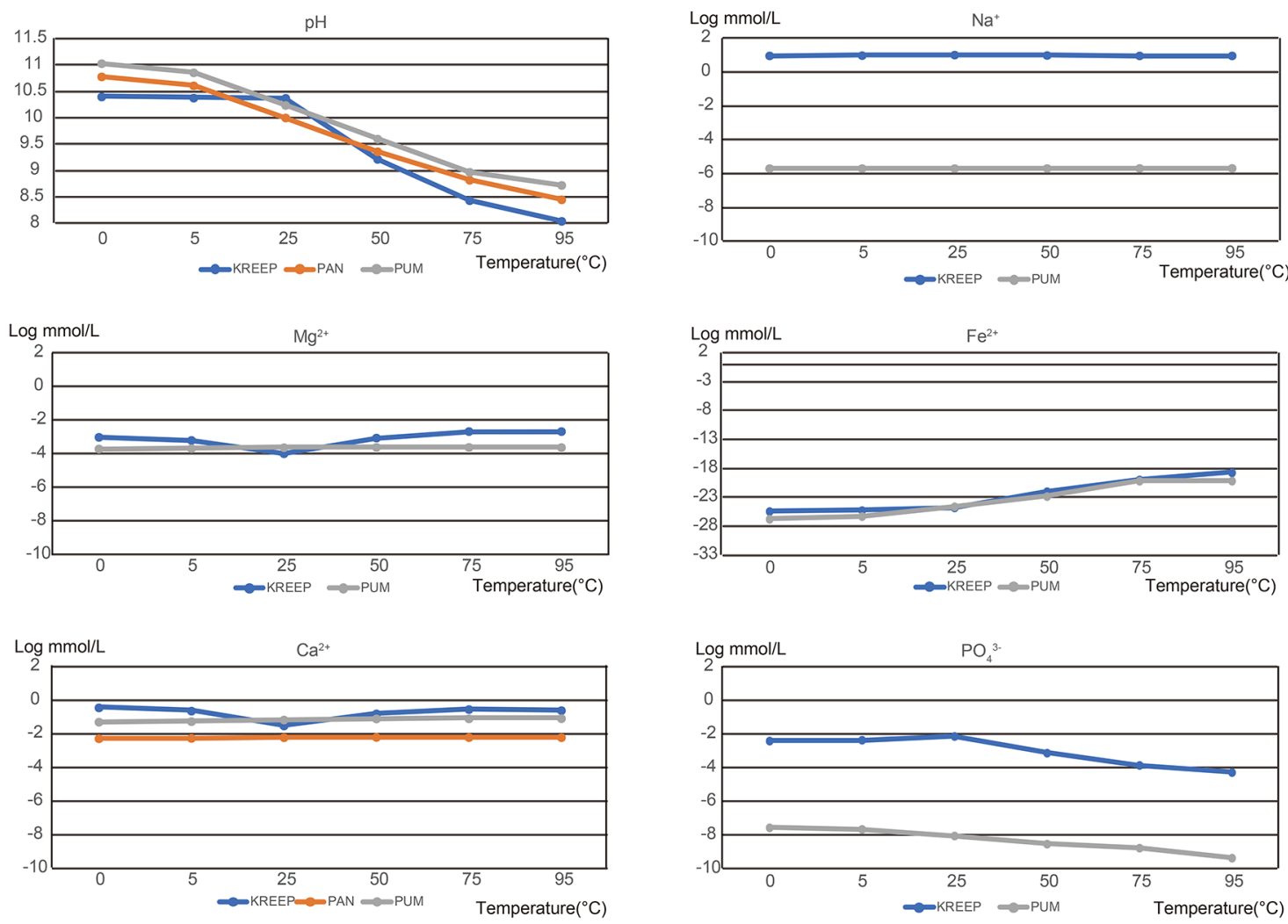

図 11 熱力学計算によって求めた KREEP玄武岩, PAN および始源的上部マントルカンラン岩（Primitive Upper Mantle: PUM） と反応した溶液中の代表的イオン濃度.

Fig. 11 Concentration of representative ions in solutions reacted with KREEP basalt, PAN, and primitive upper mantle (PUM).

$\mathrm{Fe}_{3} \mathrm{Si}_{2} \mathrm{O}_{5}(\mathrm{OH})_{4}$

$\mathrm{Fe}$-serpentinite

$$
\begin{aligned}
= & \mathrm{Fe}_{3} \mathrm{O}_{4}+\mathrm{H}_{2} \mathrm{O}+2 \mathrm{SiO}_{2(\mathrm{aq})}+\mathrm{H}_{2(\mathrm{aq})} \\
& \text { magnetite }
\end{aligned}
$$$$
3 \mathrm{Fe}(\mathrm{OH})_{2}=\mathrm{Fe}_{3} \mathrm{O}_{4}+2 \mathrm{H}_{2} \mathrm{O}+\mathrm{H}_{2(\mathrm{aq})}
$$

Fe-brucite magnetite

(2)から (4)の式の生成物をみると，マグネ夕 イトが形成されていることがわかる。これは観察 結果と一致する。カンラン石には, 鉄のほかにわ ずかにニッケルなどの遷移金属元素が含まれてい るので，蛇紋岩化によるもっとも還元的な鉱物共 生は，磁鉄鉱ペントランダイトなど（あるいはア ワル鉱，ヒーズルウッド鉱）のニッケルを含む硫
化物である（Nozaka, 2012）。蛇紋石の形成に伴 い，カンラン石中のニッケルと鉄が，少量ではあ るがペントランダイト，黄鉄鉱などの金属硫化物 を形成したと考えられる。この鉱物組み合わせか ら今回採取した白馬蛇紋岩の蛇紋岩化作用が起 こった酸素，硫黄フガシティーはおよそそれぞれ -35 から $-33,-1.6$ から -1 の範囲内と推測さ れる(Nozaka, 2012; 図 12)。

\section{1-2) ペントランダイトと金属タンパク質の関} 係

今回，蛇紋岩から鉱物分離して得られたペント ランダイト $\left(\mathrm{Ni}_{4.5} \mathrm{Fe}_{4.5} \mathrm{~S}_{8}\right)$ は鉄ニッケル硫化物で あるが，先行研究では，金属タンパク質の活性部 位の起源として，これまで認識されていなかった 


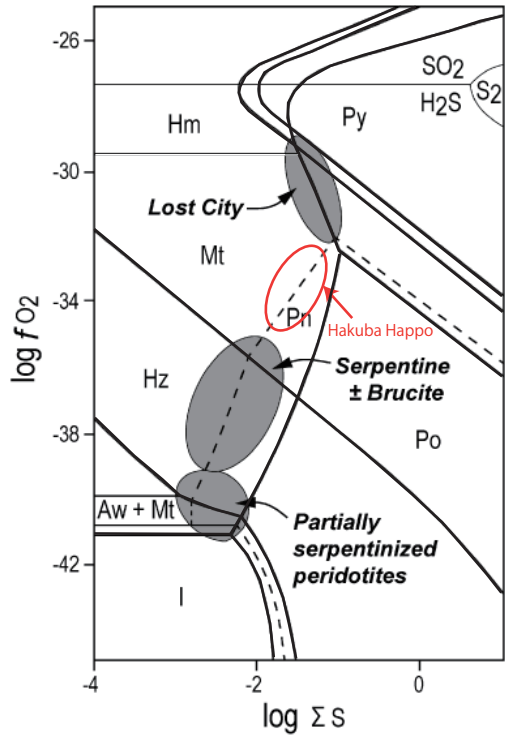

図 $12300^{\circ} \mathrm{C} ， 2 \mathrm{~kb}$ での硫化物と酸化物の安定性を示し た $\log \mathrm{f}_{\mathrm{o} 2}-\log \Sigma \mathrm{S}$ 図。太線は，熱力学計算で求め た固相間の境界線。細線は硫黄種間の境界線. 破線はペントランダイトの鉱物学的データを用 いた安定境界線。灰色部分は鉱物組み合わせの 特徵を示したもの（苦鉄質岩の部分的蛇紋岩化 が起こっている部分，蛇紋岩 City). 赤丸で示している部分が本研究の鉱物 観察で推定された白馬八方蛇紋岩の鉱物組み合 わせ (Nozaka, 2012 を改変). 図中の略字: Aw: awaruite, Hm: hematite, Hz: heazlewoodite, I: iron, Mt: magnetite, Pn: pentlandite, Po: pyrrhotite, Py: pyrite.

Fig. $12 \log \mathrm{f}_{\mathrm{o} 2}-\log \Sigma \mathrm{S}$ diagram showing sulfide and oxide stabilities at $300^{\circ} \mathrm{C}$ and $2 \mathrm{~kb}$. Heavy solid lines represent reactions between solid phases calculated from thermodynamic data; light solid lines mark boundaries between fields where various sulfur species exist. Dashed lines represent the stability limit of pentlandite inferred from petrologic data. Shaded areas indicate conditions for partially serpentinized peridotites. From observations in this study, red circled area indicates condition for Hakuba Happo serpentinite (Modified from Nozaka, 2012). Abbreviations: Aw: awaruite, Hm: hematite, Hz: heazlewoodite, I: iron, Mt: magnetite, Pn: pentlandite, Po: pyrrhotite, Py: pyrite.

鉱物である。ペントランダイトは，硫黄を介して 鉄とニッケルが結合した構造をもっており，非常 に高い伝導性をもった鉱物である。その構造的特
徵は，生体中の酵素ヒドロゲナーゼの活性部位と 類似した構造をもっている。ペントランダイトの 金属原子間距離はおよそ $2.51 \AA$ であり，Fe-Ni ヒドロゲナーゼの活性部位における原子間距離 $(\mathrm{dFeNi} \cong 2.57 \AA)$ と非常に近い值をとっている

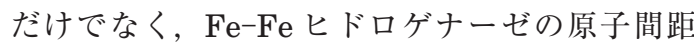
離 $(\mathrm{dFeFe} \cong 2.56 \AA)$ とも非常に近い（Nicolet et al., 1999; Ogata et al., 2015)。このような特 徵から再生可能エネルギーの分野でも注目されて おり，従来の高価な白金の代替品となりうる非常 に優れた水素触媒能をもつことが報告されている (Konkena et al., 2016)。

このように始原的な生命の代謝を担っていたで あろうヒドロゲナーセや ACS/CODH 複合体など の金属タンパク質（あるいは金属酵素）の活性部 位と初期地球の環境に存在した岩石の岩石水反応 によって二次的に形成された鉱物のもつ結晶構造 などの特徴が非常に類似していることはきわめて 興味深い。つまり，これらの酵素の起源は生命誕 生場の壁岩を構成していた二次鉱物であることを 示唆している。ACS/CODH 複合体は, Hakuba OD1がもつと推定されている炭素固定反応,

Wood-Ljungdahl pathway 中に存在する酵素の 1 つであることも重要な点である。これもまた，生 命誕生場にコマチアイト質岩石が存在したことを 示すのであろう。

\section{2）KREEP 玄武岩とペントランダイト}

コマチアイトの岩石-水反応によってヒドロゲ ナーゼや ACS/CODH 複合体のもととなる鉱物, ペントランダイトが生成することが判明した。し かしながら，コマチアイトに元来含まれる遷移金 属元素の量はきわめて微量である。とくに鉄硫黄 クラスターのもととなる硫黄がほとんど含まれて いない。それに対して，冥王代の表層にみられる 岩石のなかでも KREEP 玄武岩にはもっとも多く の金属タンパク質の形成に必要な生命必須元素が 含まれている。月の KREEP 立武岩の全岩組成 には，硫黄が主要元素として含まれており，鉄は $\mathrm{FeO}$ が $22.04 \mathrm{wt} \%$ ときわめて多く含まれている (Wänke et al., 1973; Rhodes et al., 1974)。これ は，太古代の地球上でみられる玄武岩中の鉄の 
含有量（ $\mathrm{FeO}$ が最大 $7.4 \mathrm{wt} \%$ ）と比較にならな いほど多いことがわかる（Ohta et al., 1996）。 KREEP 玄武岩から生成する二次鉱物によって, 電子伝達を行う金属タンパク質であるフェレドキ シンのもととなる鉄硫黄クラスターを多量に形成 可能であったことが推定される。

ほかにも $\mathrm{Mg}, \mathrm{Ca}, \mathrm{P}$ などが主要成分として多 く含まれており，微量成分のなかにも Zn, Co, $\mathrm{Ni}$ なと，金属タンパクの活性中心として必要な 元素が含まれている。文献值による KREEP玄 武岩中の $\mathrm{Ni}$ 含有量（図 10A）は, 現生の島弧・ 中央海嶺玄武岩のそれ（数 10 数 $100 \mathrm{ppm}$ ：川 辺，1974）と比較してとくに高いとはいえない。 しかし，ペントランダイトは，塩基性岩を母岩と するマグマ性 $\mathrm{Ni}$ 鉱床の主要鉱物であり，代表的 なものとしては，シベリアの古生代末洪水立武岩 に伴って形成された Noril'sk-Talnakh 鉱床にお ける産出が知られている。この場合, ペントラン ダイトは熱水変質ではなく, 初生的にマグマから 晶出したことになるが，冥王代の KREEP 玄武 岩生成時にも $\mathrm{Ni}$ 硫化物の濃集が起こりえたこと を示唆している。

\section{3）溶液環境の評価}

KREEP 玄武岩, PAN，および PUM と反応し た溶液の主要イオン濃度を熱力学計算によって 求めた結果は, 岩石組成と溶液組成の相対的関 係は成り立っているので，全岩組成の違いが溶 液中のイオン濃度に反映されている。しかし, KREEP 玄武岩は，その名前のとおり，K， REE (Rare earth elements : 希土類元素) と P に富 む。そのために，この岩石が水と反応した溶液 は $\mathrm{PO}_{4}{ }^{3-}$ が高濃度を示すことは当然である。一 方で, $\mathrm{Mg}^{2+}, \mathrm{Ca}^{2+}$, および $\mathrm{Fe}^{2+}$ といった主要な イオンには，岩石ごとの大きな差はみられなかっ た。近年，タンパク質を形成するための重合反応 が進行するためには，アルカリ性環境が重要で あることが実験的研究により示された（Sakata et al., 2014; Rodriguez-Garcia et al., 2015)。ま た，OD1を産出する，白馬やThe Cedarsなど の蛇紋岩熱水系も $\mathrm{pH}=10-11$ の高アルカリ環 境であることが知られている (Suda et al., 2014;
Suzuki et al., 2013, 2017)。蛇紋岩熱水系の高ア ルカリ条件は, $\mathrm{Mg}(\mathrm{OH})_{2}$ の溶解に起因すると考 えられている。本研究の熱力学計算結果による と，その他の岩石，KREEP玄武岩および PAN においても，PUM には及ばないものの，0.5 程 度の $\mathrm{pH}$ のばらつきの範囲内で，溶液は高アルカ リ性を示すことがわかった。これは，これらの岩 石に含まれる $\mathrm{CaO}$ 成分が溶出することによって, $\mathrm{CaO}+\mathrm{H}_{2} \mathrm{O} \rightleftarrows \mathrm{Ca}^{2+}+2 \mathrm{OH}^{-}$によりアルカリ溶 液が形成されるためである。よって，高アルカリ 環境という点については，コマチアイトに限らず, PAN および KREEP 立武岩においても，その条 件は達成され得たと考えられる。

このような溶液環境において, ペントランダイ 卜などの Ni 硫化物鉱物が安定に存在し得るかを, 熱力学計算によって検討した。 $\mathrm{Ni}$ および Fe 硫化 物鉱物の安定領域を, $\mathrm{fS}_{2}-\mathrm{fO}_{2}$ および $\mathrm{pH}-\mathrm{fO}_{2}$ 図 （図 13a,b）に示している。これらの図によれば, 低温の熱水環境においても，比較的低酸素フガシ ティー条件においては，Ni 硫化物は安定に存在 し得る。 Fe 硫酸塩が生成するような高酸素フガ シティーまたは酸性条件下では, Ni 硫化物は溶 解する。このことは, 硫化鉱物が金属タンパク形 成に関わっていたとすると，その環境が比較的低 酸素および高 $\mathrm{pH}$ 条件に束縛されることを示して いる。

\section{VI. 結 論}

本研究では，冥王代の表層に存在した自然原子 炉間欠泉モデルに基づき，想定した環境のなかで 当時存在した岩石の岩石一水反応によって生成す る二次鉱物から始原生命のもつ金属タンパク質が 形成されうることを解説した。

冥王代の表層を形成するおもな岩石は，コマチ アイト, KREEP 玄武岩，アノーソサイトの 3 種 類である。自然原子炉間欠泉内に流れ込んだ天水 により，コマチアイトに含まれるカンラン石と水 が非平衡状態で反応する。その反応によって水素 が発生し，間欠泉内に超還元的な環境が形成され るとともに二次鉱物が形成される。本研究では, 冥王代擬似環境のひとつである白馬八方の蛇紋岩 
(a)

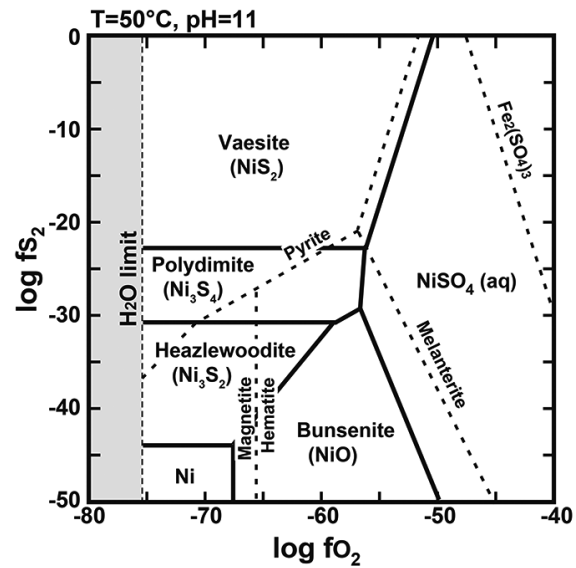

(b)

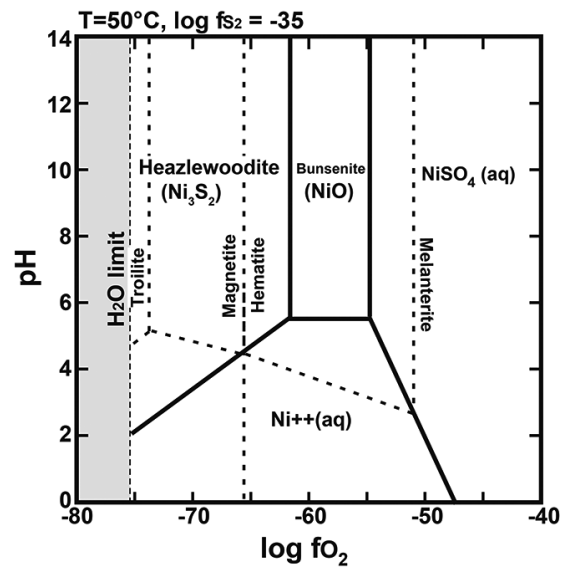

図 $1350^{\circ} \mathrm{C}$ における $\mathrm{Ni}-\mathrm{S}-\mathrm{O}-\mathrm{H}$ 系，および $\mathrm{Fe}-\mathrm{S}-\mathrm{O}-\mathrm{H}$ 系の安定条件を示した $\mathrm{fS}_{2}-\mathrm{fO}_{2}$ 図 (a)，および $\mathrm{pH}-\mathrm{fO}_{2}$ 図（b）。 計算には The Geochemist's Workbench（thermo.com.V8.R6+データセット）を使用した。実線はNi 鉱物の反応 境界，点線は $\mathrm{Fe}$ 鉱物の反応境界を示している。 Ni-S 系において Ni 端成分のペントランダイトは準安定である ため，これらの図には示されていないが，図 12 の相関係を考慮すると，ペントランダイトは，ヒーズルウッド 鉱と磁鉄鉱が共存する領域付近で安定であると推定できる.

Fig. $13 \mathrm{fS}_{2}-\mathrm{fO}_{2}$ and $\mathrm{pH}-\mathrm{fO}_{2}$ diagrams at $50^{\circ} \mathrm{C}$ in $\mathrm{Ni}-\mathrm{S}-\mathrm{O}-\mathrm{H}$ and $\mathrm{Fe}-\mathrm{S}-\mathrm{O}-\mathrm{H}$ systems. The Geochemist's Workbench with its built-in dataset "thermo.com.V8.R6+" was used for the calculations. Solid and dotted lines represent phase boundaries in $\mathrm{Ni}$ and $\mathrm{Fe}$ minerals, respectively. Pentlandite does not appear in these diagrams because of the metastability of its Ni end-member. However, regarding phase relations in Fig. 12, the stability field of pentlandite can be estimated to be in the heazlewoodite + magnetite stability field.

を用いて，蛇紋岩化作用によって形成された二次 鉱物を詳細に観察した。そして，従来から金属夕 ンパクの起源として指摘されていた鉄硫化物に加 えて鉄ニッケル硫化物であるペントランダイトが 始原生命の代謝として重要なヒドロゲナーゼや $\mathrm{ACS} / \mathrm{CODH}$ 複合体の活性部分と, その構造（と くに原子間距離）が非常に近いことを指摘した。 とくに，ACS/CODH 複合体は，Hakuba OD1 が もっていると推定されている最初期の炭素固定反 応, Wood-Ljungdahl pathway 中に存在する酵 素の 1 つであり，重要な金属タンパク質である。 しかしながら，蛇紋岩に含まれる鉄ニッケル硫化 物はごく微量である上，カンラン岩組成からは， 溶液中にリンがほとんど供給されない。

KREEP 玄武岩とアノーソサイトに関しては, 初期地球の岩石がそのまま残っている月の岩石 の全岩組成を用いて岩石一水反応の熱力学計算を 行った。蛇紋岩に含まれる鉄ニッケル硫化物が微 量であることに対して，KREEP 玄武岩の全岩組
成は，きわめて鉄に富み，金属タンパク質の生 成に必要な元素を多く含んでいる。また，初生 的にマグマから $\mathrm{Ni}$ を濃集させた後で，ペントラ ンダイトが形成された可能性がある。さらに, KREEP 玄武岩と反応した溶液中の $\mathrm{PO}_{4}{ }^{3-}$ 濃度 は，コマチアイトのそれに比べて，数桁以上も高 い濃度を示す。よって，KREEP玄武岩は，鉄硫 化物やペントランダイトなど，始原生命がもって いたと思われる金属タンパク質であるフェレドキ シン，ヒドロゲナーゼ， ACS/CODH 複合体の生 成に必要な鉱物を胚胎し, かつ生命に必須なリン の供給源となり得る。

以上のように, 冥王代の表層に存在した主要な 岩石である，コマチアイト，KREEP玄武岩，お よびアノーソサイトと水の反応が進行することで, 岩石中の陽イオンが溶けだした高アルカリ溶液が 生成し，金属硫化物鉱物が高分子有機化合物のな かの活性中心に分子として組み込まれる環境がつ くられ得ることを示した。このような環境下（図 
(A)

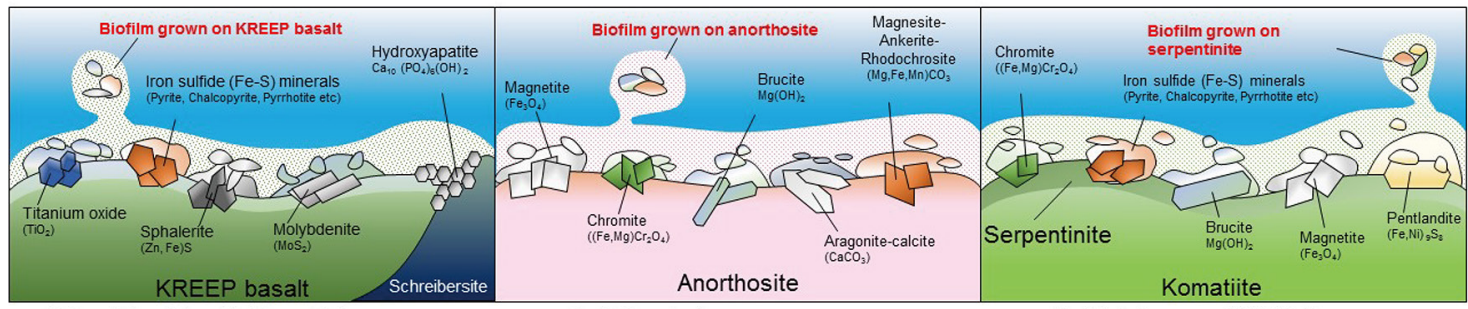

FeS: metallic protein Mo: Nitrogen fixation

$\begin{array}{ll}\text { Fes: metallic protein } & \text { Mo: Nitrogen fixation } \\ \text { Ti: Photosynthesis } & \text { Zn: RNA polymerization }\end{array}$

(B)

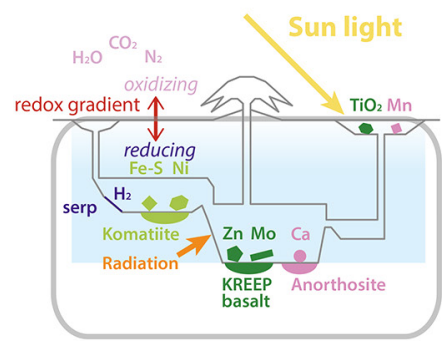

Natural Nuclear Geyser System
Mn: Photosynthesis

Ca: Communication system between cells

Cr: Metabolism

Ni: Metabolism

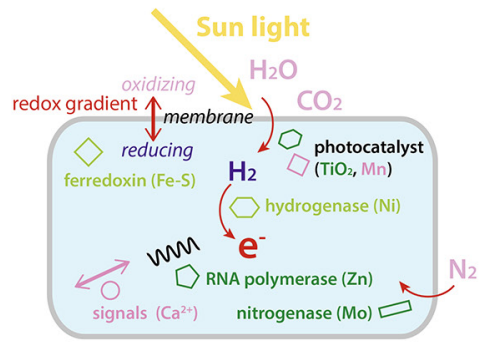

Cell

図 14 （A）岩石水反応によって形成された二次鉱物上に生じた始原生命のバイオフィルム.バイオフィルムのコロニー は変質したコマチアイト，KREEP玄武岩，アノーソサイトの表面に形成された（丸山ほか, 2019)。（B）生命誕 生場の機構と生命の機構を示した模式図. 左図は, 生命誕生場として考えられている冥王代の原初大陸上の自 然原子炬間欠泉システム内部を示したもの（Ebisuzaki and Maruyama, 2017）で，右図は原始生命の細胞を示 したものである.

Fig. 14 (A) Three types of colony of first proto-life in the form of biofilm, which develop directly above secondary minerals through water-rock interactions. Colonies were formed on the surface of altered komatiite, KREEP basalt, and anorthosite (Maruyama et al., 2019). (B) Schematic models of life as a system using energy input and redox gradient. Figure to the left shows a natural nuclear geyser system (Ebisuzaki and Maruyama, 2017), possible the original place of life in the Hadean primordial continent. The figure to the right shows a cell of primordial life.

14）ではじめての生命の化学反応が可能になっ たと考えられる。

\section{謝 辞}

本稿は, 国立遺伝学研究所の黒川 顕教授をはじめと する「冥王代生命学の創成」グループの研究者の方々 との議論を通してまとめた総説である。本原稿の査読 をして頂いた 2 人の査読者の方には非常に有益なコメ ントをいただいた。また，本論文の執筆と編集にあたり， 服部玲子氏の協力をいただいた。これらの方々に深く 感謝する。

本研究は, 科学研究費助成事業（新学術領域研究「冥 王代生命学の創成（課題番号 $26106001 ； 26106002$ )」 の助成を受けたものである。

\section{文献}

Arai, T. and Maruyama, S. (2017) : Formation of anorthosite on the Moon through magma ocean fractional crystallization. Geoscience Frontiers, 8, 299308.

Arrhenius, S. (1908): Worlds in the Making: The Evolution of the Universe. Harper \& brothers.

Baross, J.A. and Hoffman, S.E. (1985): Submarine hydrothermal vents and associated gradient environments as sites for the origin and evolution of life. Origins of Life and Evolution of the Biosphere, $\mathbf{1 5}$, 327-345.

Bertini, I., Gary, H.B., Lippard, S.J. and Valentine, J.S. (1994) : Bioinorganic Chemistry. University Science Books.

Boyet, M. and Carlson, R.W. (2007): A highly depleted moon or a non-magma ocean origin for the lunar crust?. Earth and Planetary Science Letters, 262, 
$505-516$.

Corliss, J.B., Baross, J.A. and Hoffman, S.E. (1981): An hypothesis concerning the relationship between submarine hot springs and the origin of life on Earth. Oceanologica Acta, 4, 59-69.

Damer, B. and Deamer, D. (2015): Coupled phases and combinatorial selection in fluctuating hydrothermal pools: A scenario to guide experimental approaches to the origin of cellular life. Life, 5, 872.

Darnault, C., Volbeda, A., Kim, E.J., Legrand, P., Vernède, X., Lindahl, P.A. and Fontecilla-Camps, J.C. (2003): Ni-Zn- $\left[\mathrm{Fe}_{4}-\mathrm{S}_{4}\right]$ and Ni-Ni- $\left[\mathrm{Fe}_{4}-\mathrm{S}_{4}\right]$ clusters in closed and open $\alpha$ subunits of acetyl-CoA synthase/carbon monooxide dehydrogenase. Nature Structural Biology, 10, 271-279.

Darwin, C. (1859): Origin of Species. John Murray, London, 320-324.

Dauter, Z., Wilson, K.S., Sieker, L.C., Meyer, J. and Moulis, J.M. (1997): Atomic resolution (0.94 A) structure of Clostridium acidurici ferredoxin. Detailed geometry of $[4 \mathrm{Fe}-4 \mathrm{~S}]$ clusters in a protein. Biochemistry, 36, 16065-16073.

Dobbek, H., Svetlitchnyi, V., Gremer, L., Huber, R. and Meyer, O. (2001): Crystal structure of a carbon monoxide dehydrogenase reveals a $[\mathrm{Ni}-4 \mathrm{Fe}-5 \mathrm{~S}$ ] cluster. Science, 293, 1281-1285.

Dohm, J.M. and Maruyama, S. (2015): Habitable trinity. Geoscience Frontiers, 6, 95-101.

Ebisuzaki, T. and Maruyama, S. (2017): Nuclear geyser model of the origin of life: Driving force to promote the synthesis of building blocks of life. Geoscience Frontiers, 8, 275-298.

戎崎俊一 - 西原秀典 - 黒川 顕 - 森 宙史 - 鎌形洋一 . 玉木秀幸 - 中井亮佑 · 大島 拓 - 原 正彦 - 鈴木鉄 兵・丸山茂徳 (in press)：原子炉間欠泉に駆動され た冥王代原初代謝経路. 地学雑誌. [Ebisuzaki, T., Nishihara, H., Kurokawa, K., Mori, H., Kamagata, Y., Tamaki, H., Nakai, R., Oshima, T., Hara, M., Suzuki, T. and Maruyama, S. (in press): Hadean primordial metabolism pathway driven by a nuclear geyser. Journal of Geography (Chigaku Zasshi). (in Japanese with English abstract)]

Eck, R.V. and Dayhoff, M.O. (1966): Evolution of the structure of ferredoxin based on living relics of primitive amino acid sequences. Science, 152, 363-366.

Fontecilla-Camps, J.C., Amara, P., Cavazza, C., Nicolet, Y. and Volbeda, A. (2009): Structure-function relationships of anaerobic gas-processing metalloenzymes. Nature, 460, 814-822.

Frost, B.R. (1985): On the stability of sulfides, oxides, and native metals in serpentinite. Journal of Petrology, 26, 31-63.

Gray, H.B. (2003): Biological inorganic chemistry at the beginning of the 21st century. Proceedings of the National Academy of Sciences USA, 100, 35633568.

Grimes, C.B., John, B.E., Kelemen, P.B., Mazdab,
F.K., Wooden, J.L., Cheadle, M.J., Hanghøj, K. and Schwartz, J.J. (2007): Trace element chemistry of zircons from oceanic crust: A method for distinguishing detrital zircon provenance. Geology, 35, 643646.

Hall, D.O., Cammack, R. and Rao, K.K. (1971): Role for ferredoxins in the origin of life and biological evolution. Nature, 233, 136-138.

Hug, L.A., Baker, B.J., Anantharaman, K., Brown, C.T., Probst, A.J., Castelle, C.J., Butterfield, C.N., Hernsdorf, A.W., Amano, Y., Ise, K., Suzuki, Y., Dudek, N., Relman, D.A., Finstad, K.M., Amundson, R., Thomas, B.C. and Banfield, J.F. (2016): A new view of the tree of life. Nature Microbiology, $\mathbf{1}$, $1-6$.

Iizuka, T., Komiya, T., Ueno, Y., Katayama, I., Uehara, Y., Maruyama, S., Hirata, T., Johnson, S.P. and Dunkley, D.J. (2007): Geology and geochronology of the Acasta Gneiss Complex, northwestern Canada: New constraints on its tectonothermal history. Precambrian Research, 153, 179-208.

Imaeda, Y. and Ebisuzaki, T. (2017): Tandem planet formation for solar system-like planetary systems. Geoscience Frontiers, 8, 223-231.

Johnson, J.W., Oelkers, E.H. and Helgeson, H.C. (1992): SUPCRT92: A software package for calculating the standard molal thermodynamic properties of minerals, gases, aqueous species, and reactions from 1 to 5000 bar and 0 to $1000^{\circ} \mathrm{C}$. Computers \& Geosciences, 18, 899-947.

川辺岩夫 (1974): 西南日本古生界地向斜玄武岩の遷移 元素含有量とその地質学的意義. 地質学雑誌, 80, 539-554. [Kawabe, I. (1974) : Transition metal contents of Paleozoic geosynclinal basalts in southwest Japan and their geological significance. Journal of the Geological Society of Japan, 80, 539-554. (in Japanese with English abstract) ]

Kemp, A.I.S., Wilde, S.A., Hawkesworth, C.J., Coath, D.D., Nemchin, A., Pidgeon, R.T., Vervoort, J.D. and DuFrane, S.A. (2010): Hadean crustal evolution revisited: New constraints from $\mathrm{Pb}-\mathrm{Hf}$ isotope systematics of the Jack Hills zircons. Earth and Planetary Science Letters, 296, 45-56.

Kirschvink, J.L. and Weiss, B.P. (2003): Mars, panspermia, and origin of life: Where did it all begin? Journal of Geography, 112, 187-196.

Konkena, B., Junge Puring, K., Sinev, I., Piontek, S., Khavryuchenko, O., Dürholt, J.P., Schmid, R., Tüysüz, H., Muhler, M., Schuhmann, W. and Apfel, U.-P. (2016): Pentlandite rocks as sustainable and stable efficient electrocatalysts for hydrogen generation. Nature Communications, 7, 12269-12276.

Krotev, R.L. (2005): Lunar geochemistry as told by lunar meteorites. Chemie der Erde - Geochemistry, 65, 297-346.

Kulik, D.A., Wagner, T., Dmytrieva, S.V., Kosakowski, G., Hingerl, F.F., Chudnenko, K.V. and Berner, U.R. 
(2013): GEM-Selektor geochemical modeling package: Revised algorithm and GEMS3K numerical kernel for coupled simulation codes. Computational Geosciences, 17, 1-24.

Lippard, S.J. and Berg, J.M. (1994): Principles of Bioinorganic Chemistry. University Science Books.

Ljungdahl, L.G. (1986): The autotrophic pathway of acetate synthesis in acetogenic bacteria. Annual Reviews in Microbiology, 40, 415-450.

Lubitz, W., Ogata, H., Rüdiger, O. and Reijerse, E. (2014): Hydrogenases. Chemical Reviews, 114, 40814148.

Lyon, E.J., Shima, S., Boecher, R., Thauer, R.K., Grevels, F.W., Bill, E. and Albracht, S.P. (2004): Carbon monoxide as an intrinsic ligand to iron in the active site of the iron-sulfur-cluster-free hydrogenase $\mathrm{H}_{2}$-forming methylenetetrahydromethanopterin dehydrogenase as revealed by infrared spectroscopy. Journal of the American Chemical Society, 126, 14239-14248.

Maruyama, S. and Ebisuzaki, T. (2017): Origin of the Earth: A proposal of new model called ABEL. Geoscience Frontiers, 8, 253-274.

Maruyama, S., Ikoma, M., Genda, H., Hirose, K., Yokoyama, T. and Santosh, M. (2013): The naked planet Earth: Most essential pre-requisite for the origin and evolution of life. Geoscience Frontiers, 4, 141-165.

Maruyama, S., Kurokawa, K., Ebisuzaki, T., Sawaki, Y., Suda, K., and Santosh, M. (2018): Nine requirements for the origin of Earth's life: Not at the hydrothermal vent, but in a nuclear geyser system. Geoscience Frontiers, doi:10.1016/j.gsf.2018.09.011.

丸山茂徳 ·戎崎俊一 - 黒川 顕 (2019)：地球生命誕生 場に必要な 9 条件と生命誕生場としての自然原子炉 間欠泉モデルの再考一生命誕生場は冥王代の地球表 層の 1 か所一. 地学雑誌, 128, 513-548. [Maruyama, S., Ebisuzaki, T. and Kurokawa, K. (2019): Review of the nine requirements for the birthplace of life and the nuclear geyser model: The only possible site for the birthplace of life on Hadean Earth. Journal of Geography (Chigaku Zasshi), 128, 513548. (in Japanese with English abstract) ]

Matsumoto, T. (2009): Acetyl CoA synthase, a key player of carbon fixation in nature. Bulletin of Japan Society of Coordination Chemistry, 54, 38-51. (in Japanese with English abstract)

McDonough, W.F. and Sun, S.S. (1995): The composition of the Earth. Chemical Geology, 120, 223-253.

Miller, S.L. (1953): A production of amino acids under possible primitive earth conditions. Science, 117, 528-529.

Mora, C., Tittensor, D.P., Adl, S., Simpson, A.G. and Worm, B. (2011): How many species are there on Earth and in the ocean?. PLoS Biology, 9, e1001127.

Mulkidjanian, A.Y., Bychkov, A.Y., Dibrova, D.V., Galperin, M.Y.and Koonin, E.V. (2012): Origin of first cells at terrestrial, anoxic geothermal fields. Proceedings of the National Academy of Sciences of the United States of America, 109, E821-E830.

Nakamizu, M., Okada, M., Yamazaki, T. and Komatsu, M. (1989): Metamorphic rocks in the Omi-Renge serpentinite mélange, Hida Marginal Tectonic Belt, Central Japan. Memoirs of the Geological Society of Japan, 33, 21-35. (in Japanese with English abstract).

Nicolet, Y., Piras, C., Legrand, P., Hatchikian, C.E. and Fontecilla-Camps, J.C. (1999): Desulfovibrio desulfuricans iron hydrogenase: the structure shows unusual coordination to an active site Fe binuclear center. Structure, 7, 13-23.

Nitschke, W., McGlynn, S.E., Milner-White, E.J. and Russell, M.J. (2013): On the antiquity of metalloenzymes and their substrates in bioenergetics. Biochimica et Biophysica Acta (BBA)-Bioenergetics, 1827, 871-881.

Nozaka, T. (2012) : Petrological constraints on hydrogen production during serpentinization: A review. Japanese Magazine of Mineralogical and Petrological Sciences, 41, 174-184. (in Japanese with English abstract)

Ogata, H., Nishikawa, K. and Lubitz, W. (2015): Hydrogens detected by subatomic resolution protein crystallography in a $[\mathrm{NiFe}]$ hydrogenase. Nature, 520, 571-574.

Ohta, H., Maruyama, S., Takahashi, E., Watanabe, Y. and Kato, Y. (1996): Field occurrence, geochemistry and petrogenesis of the Archean mid-oceanic ridge basalts (AMORBs) of the Cleaverville area, Pilbara craton, Western Australia. Lithos, 37, 199-221.

Ohtake, M., Matsunaga, T., Haruyama, J., Yokota, Y., Morota, T., Honda, C. and Hirata, N. (2009): The global distribution of pure anorthosite on the Moon. Nature, 461, 236-240.

Oparin, A.I. (1957): Origin of Life on the Earth. Oliver And Boyd.

O'Neil, J., Carlson, R.W., Francis, D. and Stevenson, R.K. (2008): Neodymium-142 evidence for Hadean mafic crust. Science, 321, 1828-1831.

Rhodes, J.M., Rodgers, K.V., Bansal, B.M., Wiesmann, H., Shih, C., Nyquist, L.E. and Hubbard, N.J. (1974): The relationships between geology and soil chemistry at the Apollo 17 landing site. Lunar and Planetary Science Conference Proceedings, 5, $1097-$ 1117.

Rodriguez-Garcia, M., Surman, A.J., Cooper, G.J., Suárez-Marina, I., Hosni, Z., Lee, M.P. and Cronin, L. (2015): Formation of oligopeptides in high yield under simple programmable conditions. Nature Communications, $\mathbf{6}, 8385$.

Russell, M.J. and Hall, A.J. (1997): The emergence of life from iron monosulphide bubbles at a submarine hydrothermal redox and $\mathrm{pH}$ front. Journal of the Geological Society of London, 154, 377-402. 
Russell, M.J. and Hall, A.J. (2006): The onset and early evolution of life. in Evolution of Early Earth's Atmosphere Hydrosphere, and Biosphere-Constraints from Ore Deposits edited by Kesler, S.E and Ohmoto, H., Geochemical Society of America Memoir, 198, 1-32.

Russell, M.J. and Martin, W. (2004): The rocky roots of the acetyl coenzyme-A pathway. Trends in Biochemical Sciences, 24, 358-363.

Russell, M.J., Barge, L.M., Bhartia, R., Bocanegra, D., Bracher, P.J., Branscomb, E., Kidd, R., McGlynn, S., Meier, D.H., Nitschke, W., Shibuya, T., Vance, S., White, L. and Kanik, I. (2014): The drive to life on wet and icy worlds. Astrobiology, 14, 308-343.

Sakata, K., Yabuta, H. and Kondo, T. (2014) : Effects of metal ions and $\mathrm{pH}$ on the formation and decomposition rates of di-and tri-peptides in aqueous solution. Geochemical Journal, 48, 219-230.

産業技術総合研究所地質調査総合センター編 (2015): 20 万分の 1 日本シームレス地質図 2015 年 5 月 29 日版. [Geological Survey of Japan, AIST ed. (2015) : Seamless Digital Geological Map of Japan (1:200,000).]

佐藤友彦・磯㟝行雄 - 松尾基之 (2009)：原生代末期一 古生代前期における深海の酸化還元環境: ${ }^{57} \mathrm{Fe}$ メス バウアー分光法による遠洋深海チャートの検討. 地 質学雑誌, 115, 391-399. [Sato, T., Isozaki, Y. and Matsuo, M. (2009): Redox conditions of the deep ocean in the late Neoproterozoic-Early Paleozoic: ${ }^{57} \mathrm{Fe}$ Mössbauer spectroscopic study on deep-sea pelagic chert. Journal of the Geological Society of Japan, 115, 391-399. (in Japanese with English abstract) ]

佐藤友彦・吉屋一美・丸山茂徳 $(2019)$ ：冥王代の「生 きた微化石」OD1 と超還元場の歴史. 地学雑誌， 128, 571-596. [Sato, T., Yoshiya, K. and Maruyama, S. (2019): History of the Hadean "living microfossil" OD1 and ultra-reducing environment. Journal of Geography (Chigaku Zasshi), 128, 571-596. (in Japanese with English abstract)]

Sleep, N.H. (2010): The hadean-archaean environment. Cold Spring Harbor Perspectives in Biology, 2, a002527.

Snyder, G.A., Taylor, L.A., Liu, Y. and Schmitt, R.A. (1992): Petrogenesis of the western highlands of the moon - evidence from a diverse group of whitlockiterich rocks from the Fra Mauro formation. Proceedings of Lunar and Planetary Science, 22, 399-416.

Suda, K., Ueno, U., Yoshizaki, M., Nakamura, H., Kurokawa, K., Nishiyama, E., Yoshino, K., Hongoh, Y., Kawachi, K., Omori, S., Yamada, K., Yoshida, N. and Maruyama, S. (2014): Origin of methane in serpentinite-hosted hydrothermal systems: The $\mathrm{CH}_{4}-\mathrm{H}_{2}-\mathrm{H}_{2} \mathrm{O}$ hydrogen isotope systematics of the Hakuba Happo hot spring. Earth and Planetary
Science Letters, 386, 112-125.

Suzuki, S., Ishii, S., Wu, A., Cheung, A., Tenney, A., Wanger, G., Kuenen, J.G. and Nealson, K.H. (2013): Microbial diversity in The Cedars, an ultrabasic, ultrareducing, and low salinity serpentinizing ecosystem. Proceedings of National Academy of Science USA, 110, 15336-15341.

Suzuki, S., Ishii, S., Hoshino, T., Rietze, A., Tenney, A., Morrill, P.L., Inagaki, F., Kuenen, J.G. and Nealson, K.H. (2017): Unusual metabolic diversity of hyperalkaliphilic microbial communities associated with subterranean serpentinization at The Cedars. ISME Journal, 11, 2584-2598.

Svetlitchnyi, V., Dobbeck, H., Meyer-Klaucke, W., Meins, T., Thiele, B., Römer, P., Huber, R. and Meyer, O. (2004): A functional $\mathrm{Ni}-\mathrm{Ni}-[4 \mathrm{Fe} 4 \mathrm{~S}]$ cluster in the monomeric acetyl-CoA synthase from Carboxydothermus hydrogenoformans. Proceedings of National Academy of Science USA, 101, 446-451.

Taylor, S.R. and Jakes, P. (1974): The geochemical evolution of the Moon. Proceedings of the Fifth Lunar Conference, 2, 1287-1305.

Valley, J.W., Cavosie, A.J., Ushikubo, T., Reinhard, D.A., Lawrence, D.F., Larson, D.J., Clifton, P.H., Kelly, T.F., Wilde, S.A., Moser, D.E. and Spicuzza, M.J. (2014): Hadean age for a post-magma ocean zircon confirmed by atom-probe tomography. Nature Geoscience, 7, 219-223.

Vignais, P.M. and Billoud, B. (2007): Occurrence, classification, and biological function of hydrogenases: An overview. Chemical Reviews, 107, 4206-4272.

Wänke, H., Baddenhausen, H., Dreibus, G., Jagoutz, E., Kruse, H., Palme, H. and Teschke, F. (1973): Multielement analyses of Apollo 15, 16, and 17 samples and the bulk composition of the Moon. Lunar and Planetary Science Conference Proceedings, 4, 1461.

Watson, J.D. and Crick, F.H.C. (1953): A structure for deoxyribose nucleic acid. Nature, 171, 737-738.

Weiss, M.C., Sousa, F.L., Mrnjavac, N., Neukirchen, S., Roettger, M., Nelson-Sathi, S. and Martin, W.F. (2016): The physiology and habitat of the last universal common ancestor. Nature Microbiology, $\mathbf{1}$ 16116.

Wilde, S.A., Valley, J.W., Peck, W.H. and Graham, C.M. (2001) : Evidence from detrital zircons for the existence of continental crust and oceans on the Earth 4.4 Gyr ago. Nature, 409, 175-178.

Wilson, C.J., Apiyo, D. and Wittung-Stafshede, P. (2004): Role of cofactors in metalloprotein folding. Quarterly Reviews of Biophysics, 37, 285-314.

Wood, J.A., Dickey, J.S., Marvin, U.B. and Powell, B.N. (1970) : Lunar anorthosites. Science, 167, 602604. 